\title{
Oligodendrocyte Progenitors Reversibly Exit the Cell Cycle and Give Rise to Astrocytes in Response to Interferon- $\gamma$
}

\author{
Daniel C. Tanner, Jonathan D. Cherry, and Margot Mayer-Pröschel \\ Department of Biomedical Genetics, School of Medicine and Dentistry, University of Rochester, Rochester, New York 14642
}

\begin{abstract}
Oligodendrocyte-type 2 astrocyte progenitor cells (0-2A/OPCs) populate the CNS and generate oligodendrocytes and astrocytes in vitro and in vivo. Understanding how $0-2 \mathrm{~A} / \mathrm{OPCs}$ respond to their environment is crucial to understanding how these cells function in the CNS and how to best promote their therapeutic proliferation and differentiation. We show that interferon- $\gamma($ IFN- $\gamma$ ) was not toxic to highly purified perinatal or adult rat 0-2A/OPCs. IFN- $\gamma$ treatment led to downregulation of PDGFR- $\alpha$ (platelet-derived growth factor receptor- $\alpha$ ) and Ki-67 and decreased self-renewal in clonal populations. IFN- $\gamma$ also significantly increased the proportion of cells in the $\mathrm{G}_{0} / \mathrm{G}_{1}$ phase of the cell cycle, decreased BrdU (5-bromo-2'-deoxyuridine) incorporation, and led to increased expression of the cell cycle inhibitors Rb and $\mathrm{p} 27^{\mathrm{kip} 1}$. Although $\mathrm{p} 27^{\mathrm{kip} 1}$ expression was not necessary for IFN- $\gamma$-mediated quiescence, its upstream regulator IRF-1 was required. The quiescent state of $0-2 \mathrm{~A} / \mathrm{OPCs}$ caused by IFN- $\gamma$ was reversible as the withdrawal of IFN- $\gamma$ allowed $0-2 \mathrm{~A} / \mathrm{OPCs}$ to appropriately respond to both proliferation and differentiation signals. Differentiation into oligodendrocytes induced by either thyroid hormone or CNTF was also abrogated by IFN- $\gamma$. This inhibition was specific to the oligodendrocyte pathway, as 0-2A/OPC differentiation into astrocytes was not inhibited. IFN- $\gamma$ alone also led to the generation of GFAP-positive astrocytes in a subset of 0-2A/OPCs. Together, these results demonstrate a reversible inhibitory effect of IFN- $\gamma$ on 0-2A/OPC proliferation with a concomitant generation of astrocytes. We propose that neuroinflammation involving increased IFN- $\gamma$ can reduce progenitor numbers and inhibit differentiation, which has significant clinical relevance for injury repair, but may also contribute to the generation of astrocytes.
\end{abstract}

\section{Introduction}

A number of CNS disorders exhibit dysfunction of differentiated oligodendrocytes and/or of the progenitor cells that give rise to oligodendrocytes (Franklin and ffrench-Constant, 2008). The oligodendrocyte-type 2 astrocyte progenitor cell (O-2A/OPC) that gives rise to oligodendrocytes (Raff et al., 1983; Barres et al., 1992; Levine et al., 2001; Miller, 2002; Noble et al., 2004) proliferate and migrate extensively during the first 4 postnatal weeks and persist throughout adulthood (Dawson et al., 2003; Cayre et al., 2009). O-2A/OPCs also have the potential to generate GFAP+ astrocytes with stellate morphology (also referred to as type 2 astrocytes) (Raff et al., 1983; Lillien et al., 1990; Mayer et al., 1994; Aguirre and Gallo, 2004; Windrem et al., 2004; Guo et al., 2009). In multiple sclerosis (MS), it is suggested that the repair function of O-2A/OPCs is impaired as determined by their failure to proliferate and effectively replace dying oligodendrocytes (Franklin and ffrench-

\footnotetext{
Received Nov. 9, 2010; revised Feb. 4, 2011; accepted March 2, 2011.

Author contributions: D.C.T. and M.M.-P. designed research; D.C.T. and J.D.C. performed research; D.C.T. and J.D.C. analyzed data; D.C.T. and M.M.-P. wrote the paper.

This work was supported in part by National Institutes of Health Grants ES012708 and NS39511, and New York State Department of Health Research Contract no. C023691. D.C.T. was supported in part by a Kirschstein National Research Service Award fellowship (National Institute of Neurological Disorders and Stroke Grant T32NS051152) and a postdoctoral fellowship from the National Multiple Sclerosis Society (FG1812A1). We are grateful for insight and comments from Drs. Fred Strathmann, Ibro Ambeskovic, Christoph Pröschel, Mark Noble, and Kerry O'Bannion, and to Brendan Carlin for technical assistance.

Correspondence should be addressed to either Daniel C. Tanner or Margot Mayer-Pröschel, Department of Biomedical Genetics, School of Medicine and Dentistry, 615 Elmwood Avenue, Box 633, University of Rochester, Rochester, NY 14642, E-mail: dan_tanner@urmc.rochester.edu or margot_mayer-proschel@urmc.rochester.edu.

DOI:10.1523/JNEUROSCI.5905-10.2011

Copyright $\odot 2011$ the authors $\quad 0270-6474 / 11 / 316235-12 \$ 15.00 / 0$
}

Constant, 2008). In MS brains, O-2A/OPCs have been detected at the periphery of active lesions and within chronic inactive lesions (Chang et al., 2000) but appear to be quiescent (Wolswijk, 1998a).

The reasons for O-2A/OPC failure to consistently facilitate remyelination are mostly unknown and may occur at one or all of the requisite steps: recruitment, migration, differentiation, and remyelination (Wolswijk, 1998b; Dawson et al., 2000; Levine et al., 2001). Of the many differences between developmental myelination and conditions requiring remyelination, one of the most striking is the change in the extracellular environment, which is often associated with neuroinflammation and conditions of myelin breakdown (Franklin, 2002). The proinflammatory cytokine interferon- $\gamma($ IFN- $\gamma$ ) is present during episodes of neuroinflammation and is thought to play a role in the demyelination that occurs in MS (Beck et al., 1988; Popko et al., 1997; Imitola et al., 2005). IFN- $\gamma$ expression precedes clinical symptoms of MS and exacerbates disease (Panitch et al., 1987; Beck et al., 1988), although it can be both protective and enhancing of pathology in experimental autoimmune encephalomyelitis (EAE) (Popko et al., 1997; Imitola et al., 2005; Lin and Popko, 2009).

As oligodendrocyte cell death is a major hallmark of MS, many studies have been focused on the mechanisms of IFN- $\gamma$-induced cell death. We were, however, intrigued by studies that describe quiescent oligodendrocyte progenitors surrounding MS lesion sites (Wolswijk, 1998a; Chang et al., 2000). Our specific interest was to identify mechanisms that could contribute to the failure of remyelination in the absence of cell death. We show that highly purified O-2A/OPCs dissected from the postnatal corpus callosum, and also from the adult CNS, treated with IFN- $\gamma(10 \mathrm{ng} / \mathrm{ml})$ 
exit the cell cycle. On withdrawal of IFN- $\gamma$, the cells can resume self-renewal and differentiation. Surprisingly, IFN- $\gamma$-arrested $\mathrm{O}-2 \mathrm{~A} / \mathrm{OPCs}$ were inhibited from generating oligodendrocytes but showed an increased tendency to generate GFAP + astrocytes. These results reveal that O-2A/OPCs are highly plastic cells that can withstand neuroinflammation by exiting the cell cycle and suggest that a subset of O-2A/OPCs may respond to the neuroinflammatory insult by differentiating into astrocytes.

\section{Materials and Methods}

$O-2 A / O P C$ culture. All experiments, except for those on adult cells, were performed on primary corpus callosum O-2A/OPCs isolated from postnatal day 7 rat pups by GalC-negative and A2B5-positive magnetic cell sorting (MACS) (Miltenyi Biotec) and differential adherence on tissue culture plastic as described previously (Ibarrola et al., 1996; Power et al., 2002; Li et al., 2007). All chemicals were purchased from Sigma-Aldrich unless otherwise indicated. Cells for clonal analyses were grown in proliferation media consisting of DMEM/F12 containing insulin $(1 \mathrm{mg} / \mathrm{ml})$, transferrin $(100 \mathrm{mg} / \mathrm{ml})$, putrescine $(0.1 \mathrm{~mm})$, selenium $(0.224 \mathrm{~mm})$, progesterone $(0.2 \mathrm{~mm})$, and pathocyte- 4 BSA $(0.0286 \% \mathrm{v} / \mathrm{v}$; ICN Biochemicals) approximately according to Bottenstein and Sato (1979), with the addition of $10 \mathrm{ng} / \mathrm{ml}$ PDGF-AA (PeproTech) on poly-L-lysinecoated tissue culture plastic (Nunc). Adult O-2A/OPCs were isolated from female adult optic nerve essentially as described previously (Wolswijk and Noble, 1989), with the exception that between trituration and A2B5 magnetic sorting cells were suspended in a sucrose gradient and centrifuged to separate progenitor cells from myelin debris.

For clonal analyses, 200 cells were seeded per well in a 24-well plate immediately after sorting (within $4 \mathrm{~h}$ of dissection) in $10 \mathrm{ng} / \mathrm{ml}$ PDGF-AA for $24 \mathrm{~h}$. After for $24 \mathrm{~h}$ of recovery, cells were treated as described in figure legends.

All other experiments involved first expanding O-2A/OPCs through one passage in PDGF-AA and basic fibroblast growth factor (bFGF) (10 $\mathrm{ng} / \mathrm{ml}$; PeproTech). At passage, cells were plated for experiments and allowed $24 \mathrm{~h}$ for recovery in $10 \mathrm{ng} / \mathrm{ml}$ PDGF-AA before treatment. Mass culture analyses consisted of plating O-2A/OPCs at a density of 1000 cells per well of a 24-well plate or 100,000 cells per $10 \mathrm{~cm}$ dish for Western blot. Proliferation experiments consisted of exposure to PDGF-AA $(10 \mathrm{ng} / \mathrm{ml})$ unless otherwise indicated. Differentiation conditions consisted of 1 ng/ml PDGF-AA plus $40 \mathrm{~nm}$ thyroid hormone (TH) $(30 \mathrm{ng} / \mathrm{ml}$ thyroxine and $36 \mathrm{ng} / \mathrm{ml}$ triiodothrionine) or $1 \mathrm{ng} / \mathrm{ml}$ PDGF-AA plus $10 \mathrm{ng} / \mathrm{ml}$ ciliary neurotrophic factor (CNTF) (PeproTech) as indicated in figure legends. To induce differentiation into astrocytes, O-2A/OPCs were treated with either $1 \mathrm{ng} / \mathrm{ml}$ PDGF-AA plus $10 \mathrm{ng} / \mathrm{ml}$ BMP-4 (PeproTech) or $1 \mathrm{ng} / \mathrm{ml}$ PDGF-AA plus 10\% FBS (Invitrogen) for indicated times.

Immunocytochemistry. Cells were plated as indicated. Cells were permeabilized in $0.5 \%$ Triton $\mathrm{X}-100$ and probed overnight at $4^{\circ} \mathrm{C}$ with the following antibodies, all diluted in HBSS (Invitrogen) plus 5\% fetal calf serum with $0.5 \%$ sodium azide and $0.1 \%$ Triton X-100: A2B5 (mouse IgM, hybridoma supernatant; 1:5 dilution), anti-GalC (mouse IgG3, hybridoma supernatant; 1:10 dilution), Ki-67 (mouse IgG1; 1:1000 dilution; BD Biosciences), anti-platelet-derived growth factor receptor- $\alpha$ (PDGFR- $\alpha$ ) (rabbit IgG; 1:1000 dilution; Santa Cruz Biotechnology), anti-GFAP (mouse IgG2b; 1:1000 dilution; BD Biosciences). Secondary antibodies were Alexa-conjugated 405, 488, or 568 (all used at 1:2000 dilution). Nuclei were stained with 4',6-diamidino-2-phenylindole, dihydrochloride (DAPI) (Invitrogen). Thymidine analogs 5-bromo-2'deoxyuridine (BrdU) and 5-ethynyl-2'-deoxyuridine (EdU) were from Invitrogen. Cells were rinsed in wells with $\mathrm{PBS}$ and $\mathrm{dH}_{2} \mathrm{O}$, dried, mounted with Fluoromount-G (Southern Biotechnology Associates), and coverslipped with glass. Cells were imaged on an inverted fluorescence Nikon Eclipse TE300 microscope and pictures were taken with a Spot camera using Spot software (Diagnostic Instruments).

Immunobloting. Cells were plated on $10 \mathrm{~cm}$ tissue culture dishes at $10^{5}$ cells per dish. Cells were harvested in modified radioimmunoprecipitation assay buffer containing protease and phosphatase inhibitors. O-2A/ OPC lysates were subjected to SDS-PAGE, transferred to PVDF (polyvinylidene difluoride), and probed with antibodies from Santa Cruz
Biotechnology specific against the following substrates: phospho-Rb (goat IgG; 1:1000 dilution), total-Rb (mouse IgG1; 1:1000 dilution), Actin-HRP (mouse IgG1; 1:1000 dilution), Cyclin E (rabbit IgG; 1:1000), p27 kip1 (mouse IgG1; 1:1000 dilution), and $\beta$-tubulin (rabbit IgG; 1:2500 dilution).

Quantitative real-time PCR. O-2A/OPCs were treated as described. RNA was isolated from cells and converted to cDNA following standard protocols. Taqman assays (Applied Biosystems) for p27 and IRF-1 were run multiplexed with GAPDH and values were calculated using the $\Delta \Delta C_{T}$ method. Three independent experiments were performed in triplicate.

Lentivirus propagation. Constructs containing short hairpin RNA (shRNA) sequences for p27, IRF-1, and scrambled control were purchased from Open Biosystems as inserts into the pLKO.1 vector. HEK293T cells were transfected with $2 \mu \mathrm{g}$ of pLKO.1, and the packaging vectors PAX2 $(3 \mu \mathrm{g})$ and VSV $(1.5 \mu \mathrm{g})$. Cells were fed $24 \mathrm{~h}$ after transfection with DMEM containing 1\% FetalClone II (HyClone; Thermo Fisher Scientific). At $48 \mathrm{~h}$ after feeding, viral supernatant was sterile filtered and added to O-2A/OPCs at a 1:5 dilution. Infection was allowed to proceed $4-18 \mathrm{~h}$, after which cells recovered for $24 \mathrm{~h}$ before treatment.

Flow cytometry. For DAPI cell cycle analysis, O-2A/OPCs were treated as indicated for $5 \mathrm{~d}$, detached with trypsin, and stained with DAPI. A total of 20,000 cells from each treatment was counted and DNA content determined on a BD-LSRII (BD Biosciences) and data were imported into FlowJo 8 (version 8.8.6; Tree Star) and analyzed using Modfit LT (Verity Software House). Cells from a given dissection and treatment were split to yield triplicate scans and the entire experiment was repeated three times. Cells were processed similarly for EdU incorporation and DNA content except that EdU was added $24 \mathrm{~h}$ before staining and cells were permeabilized with saponin. EdU was detected with Click-It EdU buffer (Invitrogen) at $488 \mathrm{~m}$.

Statistical analyses. Clonal analyses presented as scatterplots indicate the value of each data point from an individual experiment, with the horizontal bar indicating the mean. Summary graphs of clonal data are presented as bar charts with the means of at least three independent experiments grouped to give mean \pm SEM. All experiments were performed at least three independent times with the exception of the adult $\mathrm{O}-2 \mathrm{~A} / \mathrm{OPC}$ EdU assay and the EdU incorporation flow cytometry experiment, which were both performed two independent times. Student's $t$ test and one-way ANOVA with Bonferroni's multiple comparison post hoc test were performed as indicated using Prism 4.0 (GraphPad Software).

\section{Results}

\section{IFN- $\gamma$ inhibits $\mathrm{O}-2 \mathrm{~A} / \mathrm{OPC}$ proliferation}

To examine the response of O-2A/OPCs to IFN- $\gamma$, we first exposed highly purified progenitors to this cytokine to define concentrations in which we observed no cell death (Fig. $1 A$ ) and used a sublethal concentration throughout the rest of this work [10 $\mathrm{ng} / \mathrm{ml}$, which represents $\approx 50 \mathrm{U} / \mathrm{ml}$ (Chew et al., 2005)]. O-2A/ OPCs were grown at mass culture density (see Materials and Methods) in proliferation media [10 ng/ml PDGF-AA, the primary mitogen for O-2A/OPCs (Noble et al., 1988; Richardson et al., 1988)] in the presence or absence of IFN- $\gamma$. The number of cells expressing PDGFR- $\alpha$ was significantly decreased with IFN- $\gamma$ compared with controls (Fig. $1 C, D$; quantified in $E$ ), as was total protein expression (Fig. $1 B$ ). Treatment with IFN- $\gamma$ also decreased the number of O-2A/OPCs expressing Ki-67 compared with controls (Fig. $1 C, D$; quantified in $F$ ), which is a marker for all active phases of the cell cycle but is specifically absent from cells in the $\mathrm{G}_{0}$ phase (Scholzen and Gerdes, 2000). Mass culture analysis of O-2A/OPCs showed that continuous treatment with IFN- $\gamma$ for up to $10 \mathrm{~d}$ led to a decrease in the number of cells that expressed either Ki-67 or PDGFR- $\alpha$ (see Fig. 5).

Given the robust effect of IFN- $\gamma$ on expression of Ki-67, we next used clonal analyses to examine whether IFN- $\gamma$ suppresses $\mathrm{O}-2 \mathrm{~A} / \mathrm{OPC}$ division. We performed clonal analyses by plating $\mathrm{O}-2 \mathrm{~A} / \mathrm{OPC}$ at very low density (see Materials and Methods) and 
A

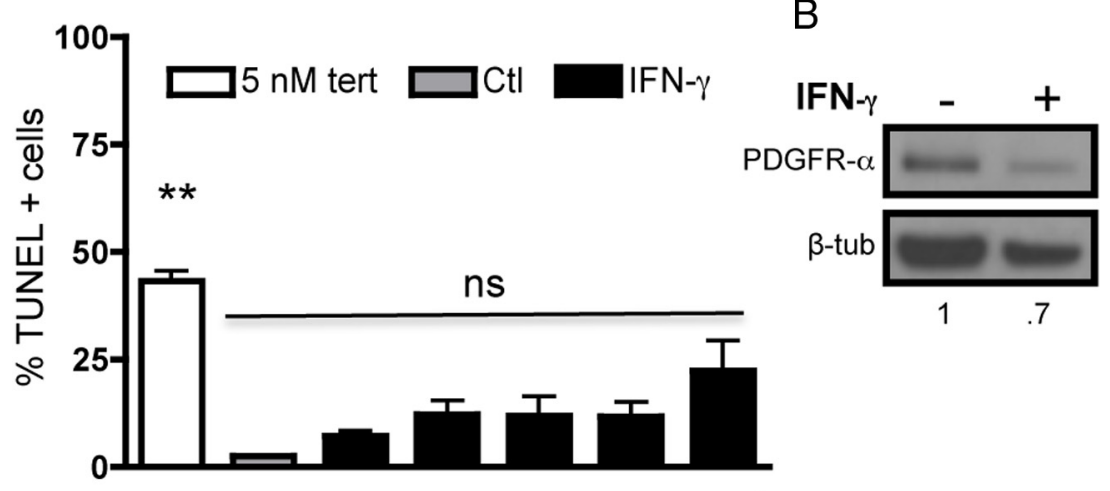

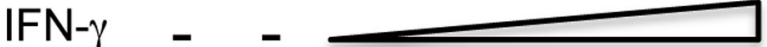

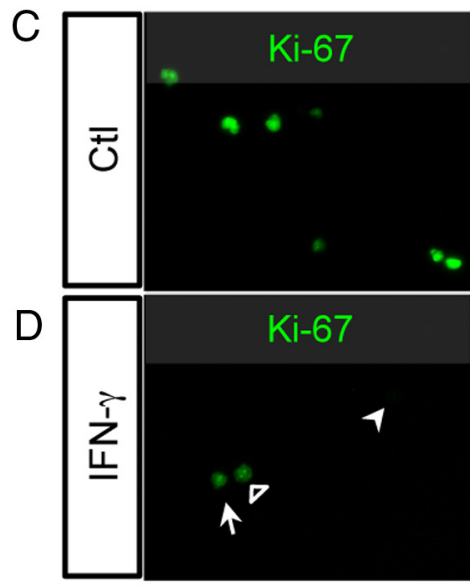

E

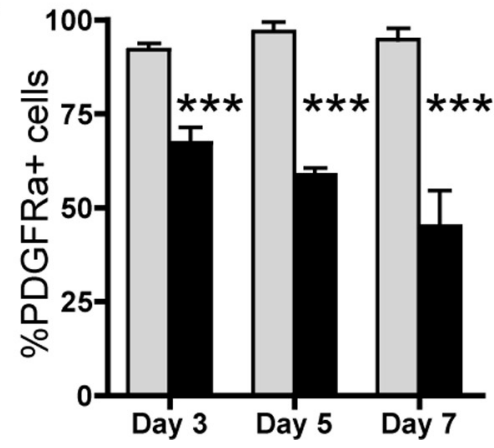

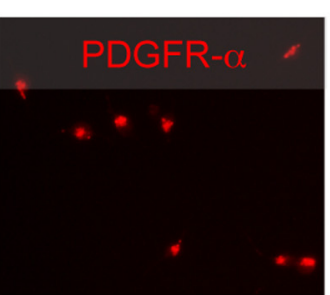
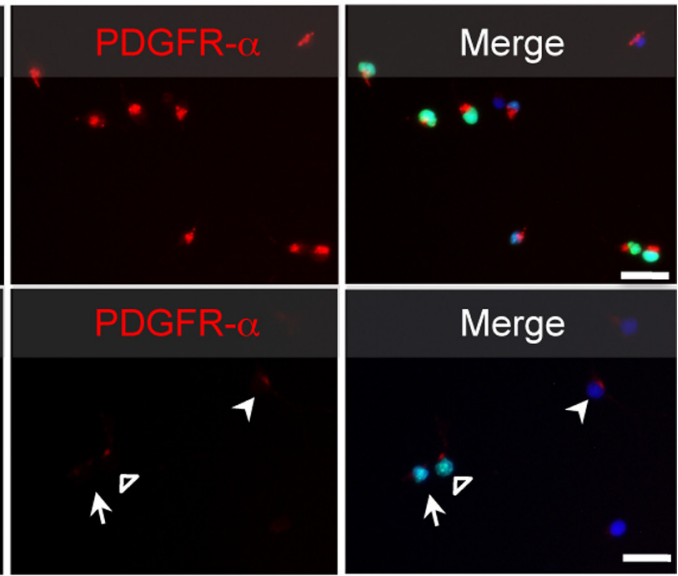

$\mathrm{F}$

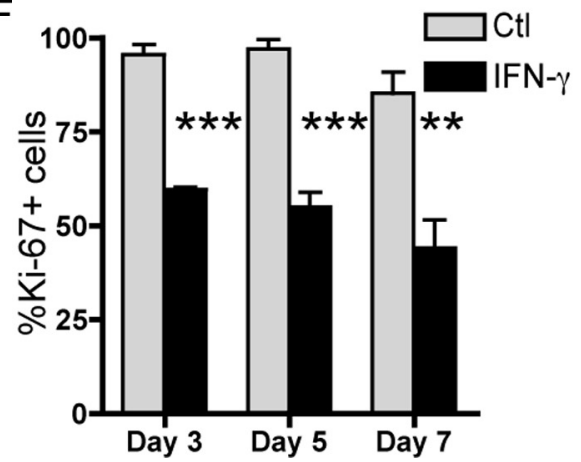

Figure 1. IFN- $\gamma$ treatment decreases PDGFR- $\alpha$ and Ki-67 expression. $\boldsymbol{A}, 0-2 \mathrm{~A} / 0 \mathrm{PC}$ were grown at mass culture density in proliferation media (DMEM/F12 media with Sato components supplemented with $10 \mathrm{ng} / \mathrm{ml} \mathrm{PDGF-AA)}$ with or without IFN- $\gamma(10$ $\mathrm{ng} / \mathrm{ml})$. 0-2A/OPCs were stained for TUNEL. Cells were treated with increasing concentrations of IFN- $\gamma(1,5,10,20,100 \mathrm{ng} / \mathrm{ml})$, and as a control for cell death some cells were treated with $5 \mu \mathrm{m}$ tert-butyl hydroperoxide. Error bars indicate mean \pm SEM of two independent experiments. ${ }^{* *} p<0.001$, relative to control; ns, no significant difference; ANOVA followed by Bonferonni's post test. $\boldsymbol{B}$, Whole-cell lysates were probed by Western blot for PDGFR- $\alpha$ and $\beta$-tubulin expression. $\boldsymbol{C}, \boldsymbol{D}$, Control-treated $(\boldsymbol{C})$ and IFN- $\gamma$-treated (D) cells were immunostained for PDGFR- $\alpha$ and Ki-67. The open arrowhead represents a double-positive cell, the closed arrowhead represents a PDGFR- $\alpha$-only positive cell, and the arrow represents a Ki-67-only positive cell. Scale bar, $25 \mu \mathrm{m}$. $\boldsymbol{E}, \boldsymbol{F}$, PDGFR- $\alpha$-positive cells $(\boldsymbol{E})$ and Ki-67-positive cells $(\boldsymbol{F})$ were counted and reported as percentage positive of the total number of DAPI-positive cells. There were significantly fewer PDGFR- $\alpha$ - and Ki-67-positive cells after treatment with IFN- $\gamma$ versus control at each time point. ${ }^{* * *} p<0.001,{ }^{* *} p<0.01, t$ test.

counted clonally derived A2B5-positive, DAPI-positive, and GalC-negative cells generated from individual O-2A/OPCs in the presence or absence of IFN- $\gamma$. Average clonal size in proliferation media containing $10 \mathrm{ng} / \mathrm{ml}$ PDGF-AA alone or in combination with bFGF, a cooperating mitogen that keeps the O-2A/OPC in a prolonged self-renewal state (Bögler et al., 1990), shows clonal expansion at $3 \mathrm{~d}$ (Fig. $2 A, D, E$ ). The addition of IFN- $\gamma$ to parallel cultures significantly decreased self-renewal of O-2A/OPCs. We confirmed that the decreased number of cells was not attributable to cell death, as IFN- $\gamma$ had no effect on the number of clones (Fig. 2D) or on terminal deoxynucleotidyl transferase-mediated biotinylated UTP nick end labeling (TUNEL) and activated caspase- 3 staining at each time point (data not shown). Average clone sizes in cultures exposed to IFN- $\gamma$ for 5 or $7 \mathrm{~d}$ were reduced by $\sim 60$ and $75 \%$ compared with cultures exposed to PDGF or PDGF plus bFGF (Fig. $2 B-E$ ). To test whether this decrease in $\mathrm{O}-2 \mathrm{~A} / \mathrm{OPC}$ self-renewal was dependent on the loss of PDGFR- $\alpha$, we pharmacologically inhibited PDGFR- $\alpha$ degradation using the lysosomal inhibitor $\mathrm{NH}_{4} \mathrm{Cl} . \mathrm{NH}_{4} \mathrm{Cl}$ had little effect on PDGFR- $\alpha$ levels in control treated cells (Fig. $2 F$ ). When O-2A/OPCs were treated with $\mathrm{NH}_{4} \mathrm{Cl}$ and IFN- $\gamma$ we found that lysosomal inhibition significantly increased PDGFR- $\alpha$ expression compared with IFN- $\gamma$ treatment alone. Clonal analysis revealed, however, that enhanced PDGFR- $\alpha$ expression did not increase O-2A/OPC self-renewal (Fig. $2 G$ ), suggesting that the effect on self-renewal is not regulated at the level of PDGFR- $\alpha$. Thus, these results demonstrate that IFN- $\gamma$ is a potent inhibitor of O-2A/OPC self-renewal.

\section{IFN- $\gamma$ treatment leads to $\mathrm{O}-2 \mathrm{~A} / \mathrm{OPC}$} cell cycle exit

To test whether the loss of proliferation occurs because of cell cycle exit, $\mathrm{O}-2 \mathrm{~A} /$ OPCs were grown at mass culture density in proliferation media treated with or without IFN- $\gamma$ in the presence of BrdU (Fig. 3A). IFN- $\gamma$ significantly decreased BrdU incorporation and PDGFR- $\alpha$ expression in $\mathrm{O}-2 \mathrm{~A} / \mathrm{OPCs}$ (Fig. $3 A-C$ ). We next measured cell cycle status by flow cytometry using the nucleic acid dye DAPI and found a significant increase in the proportion of O-2A/OPCs in $\mathrm{G}_{0} / \mathrm{G}_{1}$ and subsequently fewer in $\mathrm{G}_{2} / \mathrm{M}$ and $S$ phase [Fig. 3D; with cell cycle profiles for Ctl $\left(D^{\prime}\right)$ and IFN- $\gamma\left(D^{\prime \prime}\right)$ with representative scatterplots in inset] after exposure to IFN- $\gamma$. Considered in conjunction with the Ki-67 staining (Fig. $1 D, F$ ), these data indicate that the majority of the $\mathrm{O}-2 \mathrm{~A} /$ OPCs exposed to IFN- $\gamma$ are in the $G_{0}$ phase and therefore have exited the cell cycle. We next measured EdU incorporation and DNA content together by flow cytometry and found that there was a significant decrease in EdU incorporation and a lower average DNA content in $\mathrm{O}-2 \mathrm{~A} / \mathrm{OPCs}$ treated with IFN- $\gamma$ (Fig. $3 E, F$ ).

$\mathrm{O}-2 \mathrm{~A} / \mathrm{OPCs}$ are found in the adult CNS but have different properties from perinatal O-2A/OPCs. Cell cycle length for adult progenitors is $\sim 65 \mathrm{~h}$, compared with $\sim 16 \mathrm{~h}$ for perinatal cells, and the cells are less abundant (Wolswijk and Noble, 1989). Al- 

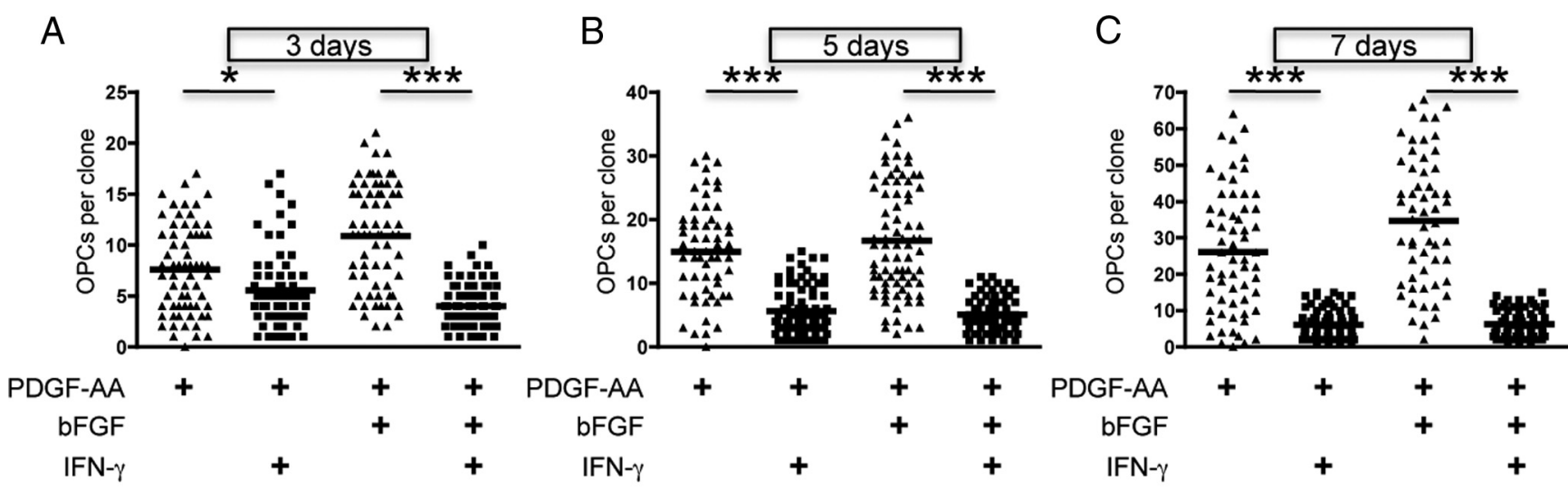

\begin{tabular}{|r|c|c|c|c|c|c|}
\hline D & cells/clone @ 3d & clones & cells/clone @ 5d & clones & cells/clone @ 7d & clones \\
\hline PDGF & $7.6 \pm 4.3$ & 66 & $15.0 \pm 7.5$ & 59 & $26.0 \pm 17.0$ & 62 \\
\hline PDGF + IFN & $5.6 \pm 3.8$ & 67 & $5.6 \pm 3.8$ & 82 & $6.1 \pm 4.0$ & 75 \\
\hline PDGF + FGF & $10.9 \pm 5.1$ & 71 & $16.7 \pm 8.7$ & 79 & $34.7 \pm 17.7$ & 58 \\
\hline PDGF + FGF + IFN & $4.0 \pm 2.1$ & 71 & $5.1 \pm 2.7$ & 73 & $6.2 \pm 3.8$ & 71 \\
\hline
\end{tabular}
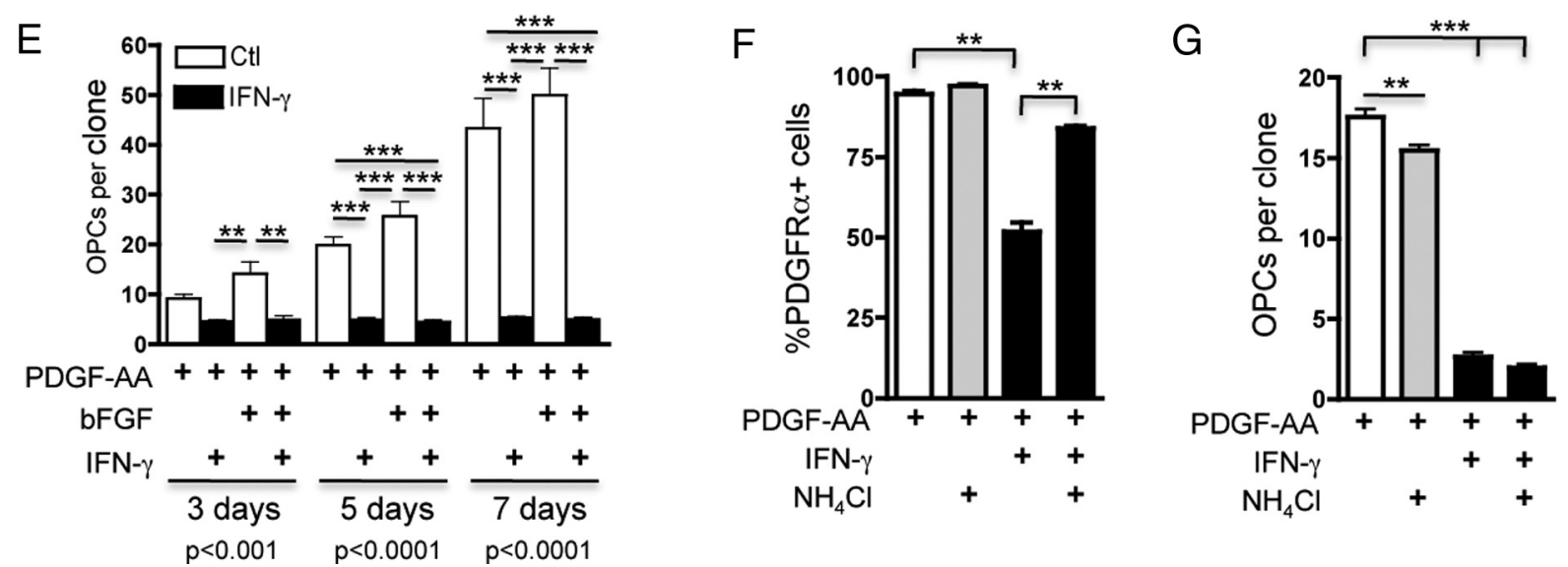

Figure 2. Interferon- $\gamma$ treatment decreases $0-2 \mathrm{~A} / \mathrm{OPC}$ self-renewal. 0-2A/OPCs were cultured at clonal density in basic growth media (DMEM/F12 with Sato components supplemented with 10 $\mathrm{ng} / \mathrm{ml}$ of the mitogen PDGF-AA as described in Materials and Methods). bFGF (10 ng/ml) was also added as indicated. Cells were treated with or without IFN- $\gamma(10 \mathrm{ng} / \mathrm{ml})$ and stained with anti-A2B5, anti-GalC, and DAPI at the indicated time points, and clonal composition was determined. Cells were counted as 0-2A/OPCs if they were A2B5+/GalC $-. A-C, A t 3 d(A), 5 d(B)$, and $7 \mathrm{~d}(\boldsymbol{C})$, $0-2 \mathrm{~A} / \mathrm{OPCS}$ treated with PDGF-AA alone or in combination with bFGF gave rise to a significantly greater number of $0-2 \mathrm{~A} / \mathrm{OPC}$ s per clone than those grown in the presence of IFN- $\gamma\left({ }^{* * * *} p<0.0001\right.$, ANOVA; ${ }^{*} p<0.05,{ }^{* * *} p<0.001$, Bonferroni's post test). $\boldsymbol{D}$, Quantification of $\boldsymbol{A}-\boldsymbol{C}$ represented as mean $\pm S D$ and number of clones counted per treatment. $\boldsymbol{A}-\boldsymbol{D}$, Representative data of one experiment. $\boldsymbol{E}$, Summary of data from four independent experiments. Means of individual experiments were grouped and data presented as mean \pm SEM. IFN- $\gamma$ exposure significantly reduced the number of $0-2 \mathrm{~A} / \mathrm{OPC}$ s per clone at $3 \mathrm{~d}\left({ }^{* *} p<0.001\right.$, ANOVA, followed by Bonferroni's post test), $5 \mathrm{~d}\left({ }^{* * *} p<0.001\right.$, ANOVA, followed by Bonferroni's post test), and $7 \mathrm{~d}\left({ }^{* * *} p<0.001\right.$, ANOVA, followed by Bonferroni's post test). $F, 0-2 \mathrm{~A} / \mathrm{OPCS}$ were grown at mass culture density and treated as indicated for $5 \mathrm{~d}$ and stained for PDGFR- $\alpha$ expression. Data are presented as mean \pm SEM $\left({ }^{* * *} p<0.0001\right.$, ANOVA, followed by Bonferroni's post test, $\left.{ }^{* *} p<0.001\right)$. G, 0-2A/OPCs were grown at clonal density for $5 \mathrm{~d}$ as indicated and A2B5 + cells were counted per clone. Data are presented as mean \pm SEM $\left({ }^{* * *} p<0.0001\right.$, ANOVA, followed by Bonferroni's post test, $\left.{ }^{* *} p<0.001\right)$.

though recent studies suggest that remyelination in adults originates from cells that behave similar to perinatal O-2A/OPCs, whether they be from the adult SVZ or adult-derived oligospheres (Zhang et al., 1999; Menn et al., 2006), we wanted to address whether adult $\mathrm{O}-2 \mathrm{~A} / \mathrm{OPCs}$ exit the cell cycle in response to IFN- $\gamma$. Adult O-2A/OPCs were cultured for 4 or $9 \mathrm{~d}$ in the presence or absence of IFN- $\gamma$. EdU incorporation was significantly decreased in cells treated for $4 \mathrm{~d}$ with IFN- $\gamma$ (Fig. 3G). Consistent with these data and that from perinatal progenitors, we found the number of clones with more than one cell was significantly decreased in the presence of IFN- $\gamma($ Fig. $3 H$ ). Finally, we determined that IFN- $\gamma$ had no significant effect on the percentage of GalC-positive cells in culture (Fig. 3I), although we found that all GalC+ cells were also A2B5 + and appeared immature (data not shown). Collectively, these data demonstrate that perinatal and adult $\mathrm{O}-2 \mathrm{~A} / \mathrm{OPCs}$ exit the cell cycle in response to IFN- $\gamma$.

IRF-1, but not $\mathrm{p} 27$, is required for IFN- $\gamma$-mediated quiescence

Having established that IFN- $\gamma$ significantly decreases O-2A/OPC self-renewal, we next sought to investigate the mechanism of these actions. We assayed levels of critical cell cycle protein expression at all time points examined. We detected a significant increase in the product of the retinoblastoma gene $\mathrm{Rb}$, whereas there was no change in the proportion of $\mathrm{Rb}$ that was phosphorylated (Fig. 4A). Rb is a tumor suppressor that prevents cell cycle progression when hypophosphorylated before the $\mathrm{G}_{1}$-to-S phase transition (Weinberg, 1991), and it has been shown that Rb levels also increase during normal cell cycle exit of CNS progenitor cells 
A
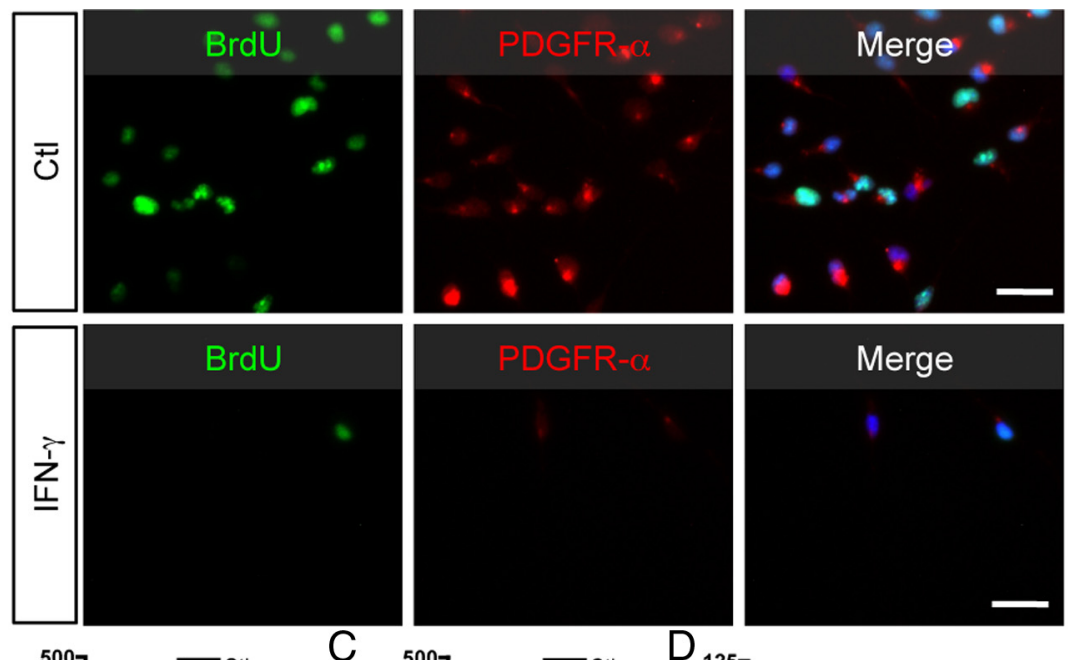

B
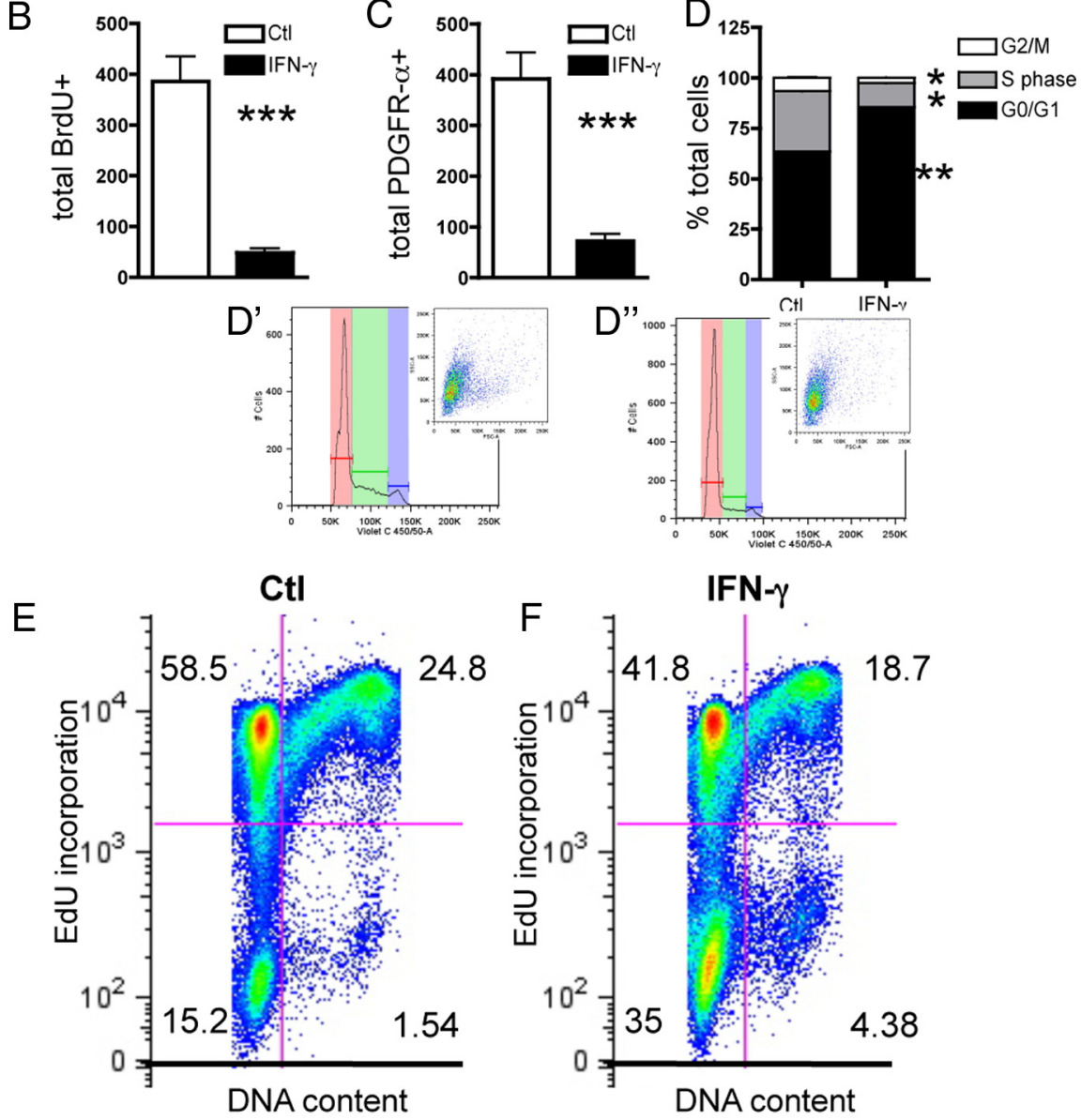

G
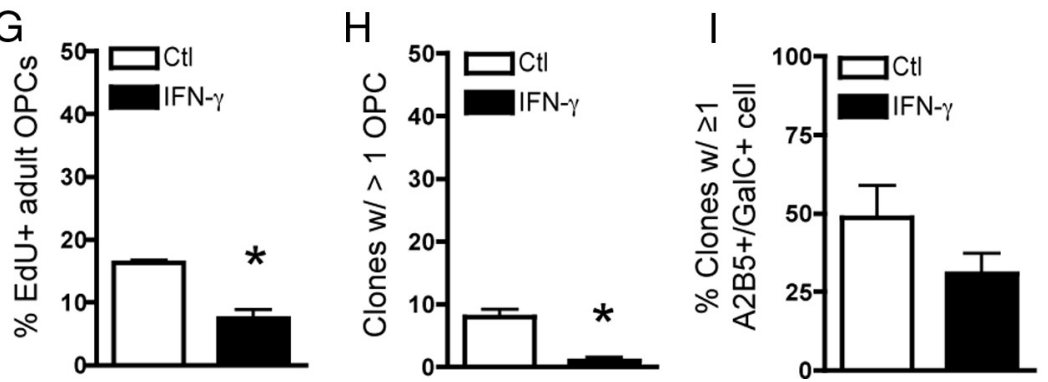

Figure 3. IFN- $\gamma$ treatment leads to cell cycle exit. $A, 0-2 A / 0 P C s$ were grown at mass culture density and treated with IFN- $\gamma$ for $3 \mathrm{~d}$. Cells were pulsed for $20 \mathrm{~h}$ with BrdU before staining. Scale bar, $25 \mu \mathrm{m}$. B, C, IFN- $\gamma$ treatment significantly decreased BrdU incorporation $\left({ }^{* * *} p<0.001, t\right.$ test) $(\boldsymbol{B})$ and PDGFR- $\alpha$ expression $\left({ }^{* * *} p<0.001, t\right.$ test) $(\boldsymbol{C})$. $\boldsymbol{D}$, IFN- $\gamma$ significantly alters the proportion of $0-2 \mathrm{~A} / \mathrm{OPC}$ in each phase of the cell cycle as analyzed by flow cytometry. Cells were grouped by phase of the cell cycle
(Burkhart and Sage, 2008). These results, in addition to the data demonstrating that these cells downregulate Ki-67 (Fig. 1D,F), strongly suggest that $\mathrm{O}-2 \mathrm{~A} / \mathrm{OPCs}$ are not progressing through the $\mathrm{G}_{1}$ restriction point and remain in the $\mathrm{G}_{0}$ phase of the cell cycle.

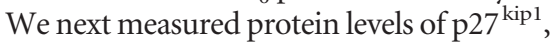
a member of the cyclin-dependent kinase inhibitor family that negatively regulates the interaction between cyclin $\mathrm{E}$ and cdk2. In order for O-2A/OPCs to differentiate into oligodendrocytes, it has been demonstrated that they need to first exit the cell cycle and then initiate their differentiation gene expression program. p2 $7^{\text {kip } 1}$ loss-of-function experiments results in massive expansion of $\mathrm{O}-2 \mathrm{~A} / \mathrm{OPCs}$ in vivo (Casaccia-Bonnefil et al., 1999), whereas gain-of-function experiments generated $\mathrm{O}-2 \mathrm{~A} / \mathrm{OPCs}$ that never acquired typical oligodendrocyte markers (Tikoo et al., 1998; Tang et al., 1999). In our experiments, $\mathrm{p} 27^{\mathrm{kip} 1}$ was significantly upregulated by $3 \mathrm{~d}$ with IFN- $\gamma$ treatment (Fig. $4 B$ ) consistent with cell cycle exit. We also measured levels of Cyclin E, which is upregulated on transition from $G_{1}$ to $S$ phase and found no change between control and IFN- $\gamma$ treatment. Next, we measured p27 gene expression over time after IFN- $\gamma$ treatment (Fig. 4C) and found that p27 transcription increased within $1 \mathrm{~h}$ and was significantly greater than expression levels in controls by $3 \mathrm{~d}$.

To investigate the necessity of p27 in IFN- $\gamma$-mediated quiescence, we knocked down p27 expression using lentiviral-based shRNA. This knockdown significantly increased proliferation in PDGF-AA-exposed $\mathrm{O}-2 \mathrm{~A} / \mathrm{OPCs}$, as predicted, compared with

$\leftarrow$

and expressed as percentage of total cell number. The proportion of $0-2 A / 0 P C s$ in $G_{0} / G_{1}$ was significantly upregulated $\left({ }^{* *} p<0.005\right.$, $t$ test), whereas the proportion in $G_{2} / M$ and $S$ phase were both significantly decreased $\left({ }^{*} p<0.01, t\right.$ test). Representative examples of ModFit cell cycle analysis for control-treated cells $\left(\boldsymbol{D}^{\prime}\right)$ and IFN- $\gamma$-treated cells $\left(\boldsymbol{D}^{\prime}\right)$ with insets of representative scatterplots. $E, F, I F N-\gamma$ decreases EdU incorporation and DNA content. $0-2 \mathrm{~A} / \mathrm{OPC}$ s were analyzed by flow cytometry as above with a different DNA content dye and the thymidine analog EdU. Numbers represent the proportion of cells in each quadrant. G-I, Adult $0-2 \mathrm{~A} / \mathrm{OPC}$ s were isolated from optic nerve as described and grown in culture for $4 \mathrm{~d}$ as indicated. G, Cells were pulsed with EdU for $48 \mathrm{~h}$ (days 3 and 4 in culture). Adult progenitors exposed to IFN- $\gamma$ incorporated significantly less EdU than did controls $\left({ }^{*} p<0.05, t\right.$ test). $\boldsymbol{H}$, Adult progenitors were plated at clonal density and maintained as described for $9 \mathrm{~d}$ in culture. Almost no clones exposed to IFN- $\gamma$ had more than one cell at $9 \mathrm{~d}$, whereas controltreated cells had significantly more clones with more than one cell $\left({ }^{*} p<0.05, t\right.$ test). $I$, Adult progenitors exposed to IFN- $\gamma$ showed no difference in the proportion of GalC + cells, although it was notable that all GalC + cells were also A2B5+. Error bars represent mean \pm SEM. 
control cells treated with lentivirus expressing scrambled shRNA (Fig. 4E). Surprisingly, however, we observed that O-2A/ OPC proliferation was still significantly decreased in p27 knockdown cells on the addition of IFN- $\gamma$, indicating that, although p27 is an important component of cell cycle progression, it is not necessary for IFN- $\gamma$ mediated quiescence (Fig. $4 E, F$ ).

We next asked whether IFN- $\gamma$ signaling through the IFN- $\gamma$ response factor, IRF-1, which is immediately upstream of IRF-1 (Lee et al., 2005), might be required for IFN- $\gamma$-induced quiescence. We found that, within $15 \mathrm{~min}$, IFN- $\gamma$ treatment highly upregulated IRF-1 gene expression (Fig. 4D). To test whether this upregulation was required for IFN- $\gamma$-meditated quiescence, we infected cells with lentivirus expressing shRNA against IRF-1 and found that there was no decrease in $\mathrm{O}-2 \mathrm{~A} /$ OPC self-renewal in the presence of IFN- $\gamma$, indicating that IRF-1 is critical for IFN- $\gamma$-mediated quiescence (Fig. $4 E, F$ ). Collectively, these data demonstrate that, although the loss of individual cell cycle inhibitors is important for O-2A/OPC cell cycle control, the robust cell cycle exit induced by IFN- $\gamma$ likely involves multiple factors that are downstream of the transcription factor IRF-1.

\section{IFN- $\gamma$-induced cell cycle exit}

is reversible

Data presented thus far demonstrate that a large proportion of $\mathrm{O}-2 \mathrm{~A} / \mathrm{OPC}$ exit the cell cycle on exposure to IFN- $\gamma$. Since IFN- $\gamma$ is associated with many types of neuroinflammation, we wanted to determine whether transient exposure to IFN- $\gamma$ would permanently inhibit O-2A/ OPC proliferation and differentiation into oligodendrocytes. To test the potential of O-2A/OPCs after IFN- $\gamma$ exposure, cells were treated for $3 \mathrm{~d}$ with IFN- $\gamma$ in proliferation media. At this time, IFN- $\gamma$ was either withdrawn to allow for 1, 2, 3, 5, or $7 \mathrm{~d}$ of recovery or IFN- $\gamma$ remained in the medium. O-2A/OPCs were plated at clonal density and the number of A2B5positive cells per clone was counted (Fig. $5 A, B)$. Within $3 \mathrm{~d}$ after IFN- $\gamma$ withdrawal, there was a significant increase in O-2A/OPC proliferation (Fig. $5 A, B$ ), which continued through $7 \mathrm{~d}$ (Fig. $5 A, B$ ). Although cultures in which IFN- $\gamma$ was withdrawn showed increased self-renewal, there was no increase in the number of O-2A/OPCs per clone during continuous IFN- $\gamma$ treatment. Critically, however, there was still the same number of clones in both treatments, indicating that these cells were still alive for up to $10 \mathrm{~d}$ with IFN- $\gamma$ exposure. Moreover, these cells still labeled with the A2B5 monoclonal antibody, suggesting that they had not lost their progenitor cell identity. O-2A/ OPCs also retained the ability to differentiate into GalC-positive oligodendrocytes after IFN- $\gamma$ withdrawal (Fig. $5 C$ ). As early as $2 \mathrm{~d}$

A

C

$\mathrm{E}$
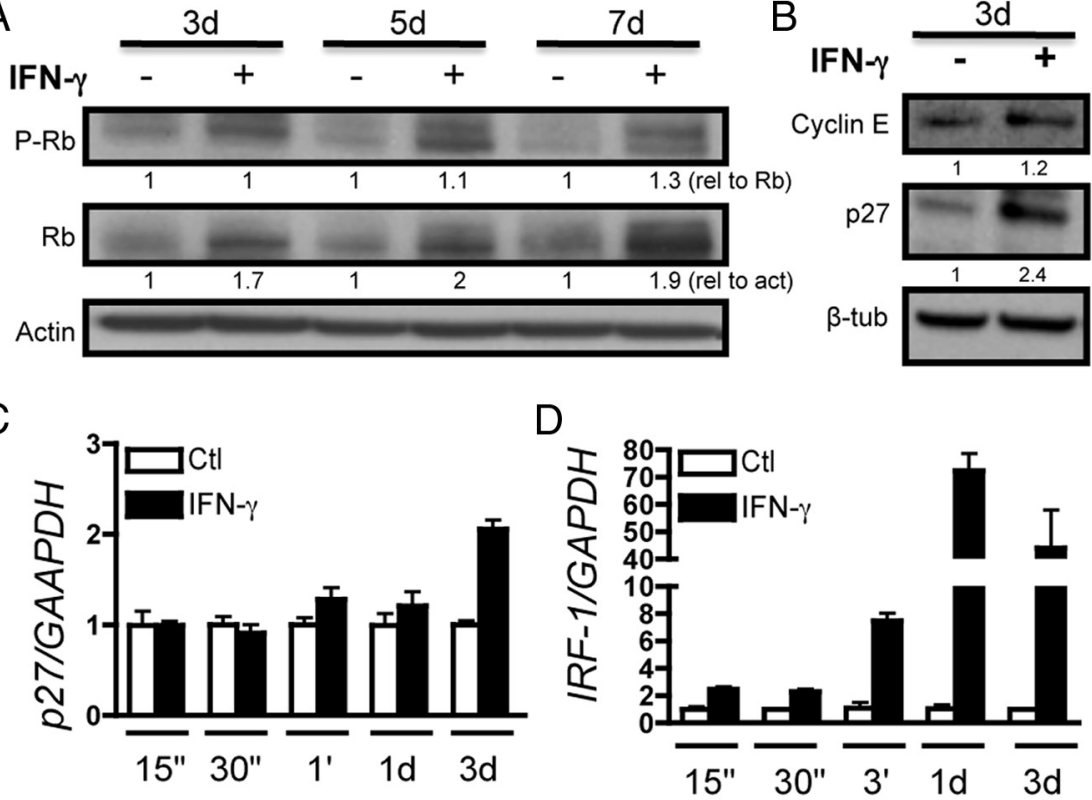

$\mathrm{F}$

Figure 4. IRF-1 is required for IFN- $\gamma$-mediated quiescence. $A$, Whole-cell lysates obtained from $0-2 A / O P C$ s treated for indicated times were probed for phospho-Rb, quantified, and normalized against total $\mathrm{Rb}$ expression. Total $\mathrm{Rb}$ protein was quantified and normalized to actin intensity. $\boldsymbol{B}$, Western blot analysis was performed for cyclin E and p27 and normalized to $\beta$-tubulin. $\boldsymbol{C}, \boldsymbol{D}$, $0-2 \mathrm{~A} / 0 \mathrm{PC}$ s were treated for the indicated times with control or IFN- $\gamma$ and RNA was isolated for RT-qPCR of p27, IRF-1, and GAPDH. 列 treated cells). IRF-1 gene expression was significantly greater at each time point tested ( $p<0.05, p<0.001$, $t$ test vs controltreated cells). $\boldsymbol{E}, 0-2 \mathrm{~A} / 0 \mathrm{PC}$ g grown at clonal density were infected with lentivirus-expressing shRNA constructs against p27, IRF-1, RRNA infected cells ( ${ }^{*} p<0.05, t$ test). p27 shRNA lentivirus infection had a significant effect on self-renewal in control-treated 政 $p<001, t$ test vs control-treated scrambled shRNA-infected cells). IFN- $\gamma$ treatment reduced self-renewal in p27 shRNA-treated cells to control levels. IRF-1 shRNA abrogated IFN- $\boldsymbol{\gamma}$-mediated quiescence. $\boldsymbol{F}$, Representative images of clones under each condition. Scale bar, $25 \mu \mathrm{m}$.

after IFN- $\gamma$ withdrawal, there was a significant increase in the number of clones containing at least one GalC-positive oligodendrocyte, thus indicating that IFN- $\gamma$-treated O-2A/OPCs can reengage in both proliferation and differentiation.

We next confirmed the clonal data in mass culture experiments. O-2A/OPCs arrested in the cell cycle by IFN- $\gamma$ showed a robust increase in the percentage of cells expressing $\mathrm{Ki}-67$ or PDGFR- $\alpha$ and an increase in the number of O-2A/OPCs after the withdrawal of IFN- $\gamma$ (Fig. 5D). The increase in Ki-67 labeling indicates that a greater proportion of $\mathrm{O}-2 \mathrm{~A} / \mathrm{OPCs}$ are entering the active phases of the cell cycle (Fig. 5D). The increase in PDGFR- $\alpha$-positive cells suggests that O-2A/OPCs regain the 

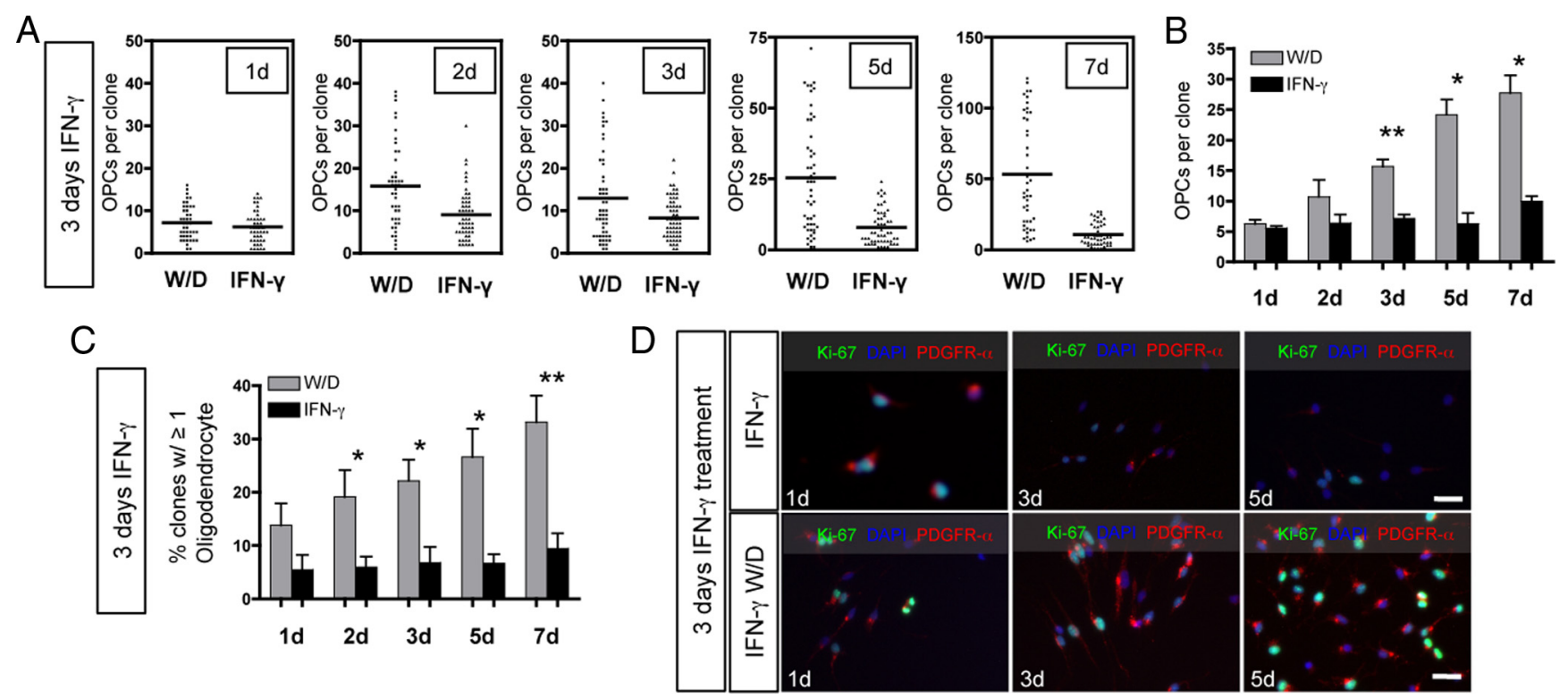

Figure 5. Withdrawal of IFN- $\gamma$ enables $0-2 \mathrm{~A} / \mathrm{OPC}$ self-renewal and spontaneous differentiation. $0-2 \mathrm{~A} / \mathrm{OPCs}$ were grown at clonal density and treated with IFN- $\gamma(10 \mathrm{ng} / \mathrm{ml})$ and $10 \mathrm{ng} / \mathrm{ml}$ PDGF-AA for $3 \mathrm{~d}$. W/D refers to cultures in which IFN- $\gamma$ was withdrawn after $3 \mathrm{~d}$ and media was replaced with control proliferation media (DMEM/F12 media with Sato components and PDGF-AA; $10 \mathrm{ng} / \mathrm{ml}$ ) for the given number of days indicated. IFN- $\gamma$ treatment consisted of $3 \mathrm{~d}$ of IFN- $\gamma$ followed by additional IFN- $\gamma$ treatment for the number of days indicated. $A$, At $1 \mathrm{~d}$ after IFN- $\gamma$ withdrawal, proliferation of 0-2A/OPCs was not different from cells exposed to IFN- $\gamma$ for 1 more day. At all other time points tested (as indicated), there was a significant increase in the number of OPCs per clone after IFN- $\gamma$ withdrawal ( $2 \mathrm{~d}, p<0.0001 ; 3 \mathrm{~d}, p=0.0021 ; 5 \mathrm{~d}, p<0.0001 ; 7 \mathrm{~d}, p<0.0001$, respectively, $t$ test vs IFN- $\gamma$ treatment). Data represent one experiment. $\boldsymbol{B}$, Summary of data from multiple experiments. Means of individual experiments were grouped and data presented as mean \pm SEM. IFN- $\gamma$ withdrawal significantly increased the number of $0-2 \mathrm{~A} / \mathrm{OPCS}$ per clone $\left({ }^{*} p<0.05,{ }^{* *} p<0.01, t\right.$ test). C, Summary data of multiple experiments in which clones from each time point were analyzed for GalC-expressing oligodendrocytes and are reported as the percentage of clones with at least one GalC-positive cell. There were significantly more clones with oligodendrocytes after IFN- $\gamma$ withdrawal at each time point after $1 \mathrm{~d}\left({ }^{*} p<0.05\right.$, ${ }^{* *} p<0.01, t$ test). $\boldsymbol{D}$, Representative images of similar experiments grown at mass culture density for $3 \mathrm{~d}$ with IFN- $\gamma$ followed by withdrawal of IFN- $\gamma$ (bottom panel) and with IFN- $\gamma$ (top panel) for another 1 , 3 , and 5 d. Cells were stained with anti-Ki-67, anti-PDGFR- $\alpha$, and DAPI. Scale bar, $25 \mu \mathrm{m}$.

ability to respond to this mitogen after exiting the cell cycle (Fig. $5 D$ ). Together, these data demonstrate that O-2A/OPCs maintain their proliferative potential and regain their responsiveness to PDGF. To determine whether these cells were able to reenter the cell cycle after a longer exposure to IFN- $\gamma$, we treated cells for $7 \mathrm{~d}$ before withdrawal. O-2A/OPCs rapidly increased expression of both PDGFR- $\alpha$ and Ki-67 on IFN- $\gamma$ withdrawal (Fig. $6 A, B$ ) and incorporated $\mathrm{BrdU}$ (Fig. $6 C, D$ ). At $7 \mathrm{~d}$ after withdrawal, there were significantly more BrdU- and PDGFR- $\alpha$-positive cells compared with continuous IFN- $\gamma$ treatment (Fig. 6D). Collectively, these data indicate that $\mathrm{O}-2 \mathrm{~A} / \mathrm{OPC}$ can remain in cell cycle phase $\mathrm{G}_{0}$ for long periods of time while still retaining the ability to reenter the cell cycle, proliferate, and differentiate.

\section{IFN- $\gamma$ treatment abrogates differentiation of $\mathrm{O}-2 \mathrm{~A} / \mathrm{OPCs}$ into oligodendrocytes}

As cessation of division is associated with differentiation of O-2A/OPCs into oligodendrocytes (Noble et al., 1988), it was surprising that our results indicated that there was far less spontaneous differentiation in the presence of IFN- $\gamma$ (Fig. $5 C$ ), as these cells were grown in proliferation medium, versus that of control-treated cells. We therefore asked whether IFN- $\gamma$ altered differentiation into oligodendrocytes. We tested the differentiation capacity of O-2A/OPCs by growing cells at clonal density in medium supplemented with a low concentration of PDGF-AA ( $1 \mathrm{ng} / \mathrm{ml})$ and thyroid hormone (40 nM) in the presence or absence of IFN- $\gamma$. After 3, 5, or $7 \mathrm{~d}$, cells were labeled with A2B5 and anti-GalC antibodies and clones were counted. The conditions we used that promote differentiation still allowed for a small degree of proliferation, but there was no significant proliferation in either condition (Fig. $7 A, B)$. There were, however, significantly fewer GalC-positive oligodendrocytes in the presence of IFN- $\gamma$, suggesting that O-2A/ OPCs exposed to IFN- $\gamma$ do not differentiate into oligodendrocytes (Fig. 7C). At day 5, there were over fourfold fewer clones with GalC-positive oligodendrocytes in the presence of IFN- $\gamma$, and by day 7 there were over sixfold fewer oligodendrocytecontaining clones with IFN- $\gamma$ treatment compared with control cultures that demonstrated robust differentiation (Fig. 7C). We also performed similar experiments with O-2A/OPCs grown in proliferation media as in Figure 1 and found that there was no change in the proportion of cells that became GalC positive ( $<3 \%$ of clones contained at least one oligodendrocyte) (data not shown).

Although thyroid hormone is a particularly well characterized pro-oligodendrocyte differentiation factor, we performed similar experiments with CNTF, which has also been shown to promote oligodendrocyte differentiation from postnatal O-2A/OPCs (Barres et al., 1993; Mayer et al., 1994). Although CNTF treatment alone leads to an increase in O-2A/OPC proliferation followed by differentiation (Fig. $7 D-F$ ), this proliferation and differentiation was significantly inhibited by IFN- $\gamma$ (Fig. $7 D-F)$. The percentage of clones containing at least one GalC-positive oligodendrocyte was reduced significantly at 5 and $7 \mathrm{~d}$ with an approximately fivefold reduction and approximately sevenfold reduction, respectively, in the number of clones containing at least one GalC-positive oligodendrocyte with IFN- $\gamma$ treatment (Fig. 7E). These results demonstrate that IFN- $\gamma$ treatment abrogates the prodifferentiation effects of at least two distinct pro-oligodendrocyte differentiation factors. 


\section{IFN- $\gamma$ promotes $\mathrm{O}-2 \mathrm{~A} / \mathrm{OPC}$} differentiation into GFAP+ astrocytes $\mathrm{O}-2 \mathrm{~A} / \mathrm{OPCs}$ were originally noted for their ability to generate type 2 astrocytes, in addition to oligodendrocytes, with the addition of serum (Raff et al., 1983), certain signaling factors in combination with extracellular matrix molecules (Lillien et al., 1990; Mayer et al., 1994), or bone morphogenic proteins (BMPs) (Mabie et al., 1997), endogenous signaling factors of the TGF- $\beta$ family. We were therefore interested in determining whether IFN- $\gamma$ would inhibit the induced differentiation into type 2 astrocytes as it inhibited induced differentiation into oligodendrocytes. We found that IFN- $\gamma$ had no inhibitory effect on O-2A/OPC differentiation into type 2 astrocytes as virtually all of the cells in culture expressed GFAP after treatment with BMP-4 alone or in combination with IFN- $\gamma$, respectively at 3, 5, and $7 \mathrm{~d}$ (Fig. 7G,H). All astrocytes were GFAP/A2B5 double positive and GalC negative, consistent with the type 2 astrocyte antigenic phenotype. Similarly, IFN- $\gamma$ did not inhibit differentiation into astrocytes induced by $10 \%$ fetal bovine serum (data not shown).

We next determined whether IFN- $\gamma$ had any effect on astrocyte generation in the absence of differentiation factors or in the presence of pro-oligodendrocyte differentiation conditions. O-2A/OPCs grown in $1 \mathrm{ng} / \mathrm{ml}$ PDGF-AA in the presence of IFN- $\gamma$ gave rise to significantly more GFAP-positive astrocytes compared with the absence of IFN- $\gamma$ (Fig. 8A,B). The percentage of astrocytes was, however, never more than $10 \%$, unlike that observed in BMP-4 or serum. Finally, $\mathrm{O}-2 \mathrm{~A} / \mathrm{OPC}$ differentiation into astrocytes was promoted by IFN- $\gamma$ even in the presence of the pro-oligodendrocyte differentiation factors TH (Fig. 8C) and CNTF (data not shown), whereas the absence of IFN- $\gamma$ allowed for no astrocyte generation in the presence of TH at any time point examined (Fig. 8C).

\section{$\mathrm{O}-2 \mathrm{~A} / \mathrm{OPCs}$ directly differentiate into GFAP+ astrocytes}

Based on our results that IFN- $\gamma$ treatment led to an increase in GFAP-positive cells, we became concerned with the formal possibility of having a small number of contaminating GFAP+/ $\mathrm{A} 2 \mathrm{~B} 5$ - type 1 astrocytes in our O-2A/OPC cultures that might have been converted by IFN- $\gamma$ into the GFAP +/A2B5 + positive cell population we observed. To test whether IFN- $\gamma$ could lead to hypertrophy and/or an upregulation of both A2B5 and GFAP in type 1 astrocytes, cultures of type 1 astrocytes generated from the postnatal day 1 rat brain were grown and treated in the presence of TH or BMP-4 with and without IFN- $\gamma$ and stained with A2B5 antibody, anti-GFAP, and DAPI (data not shown). There was no upregulation of either GFAP or A2B5 staining in cortical-derived type 1 astrocytes on treatment with IFN- $\gamma$ (data not shown). This
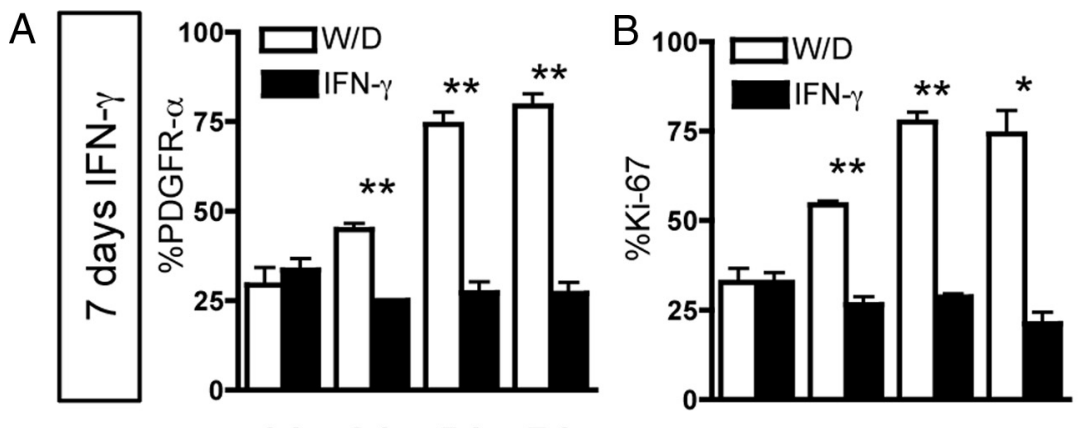

1d $3 d \quad 5 d \quad 7 d$
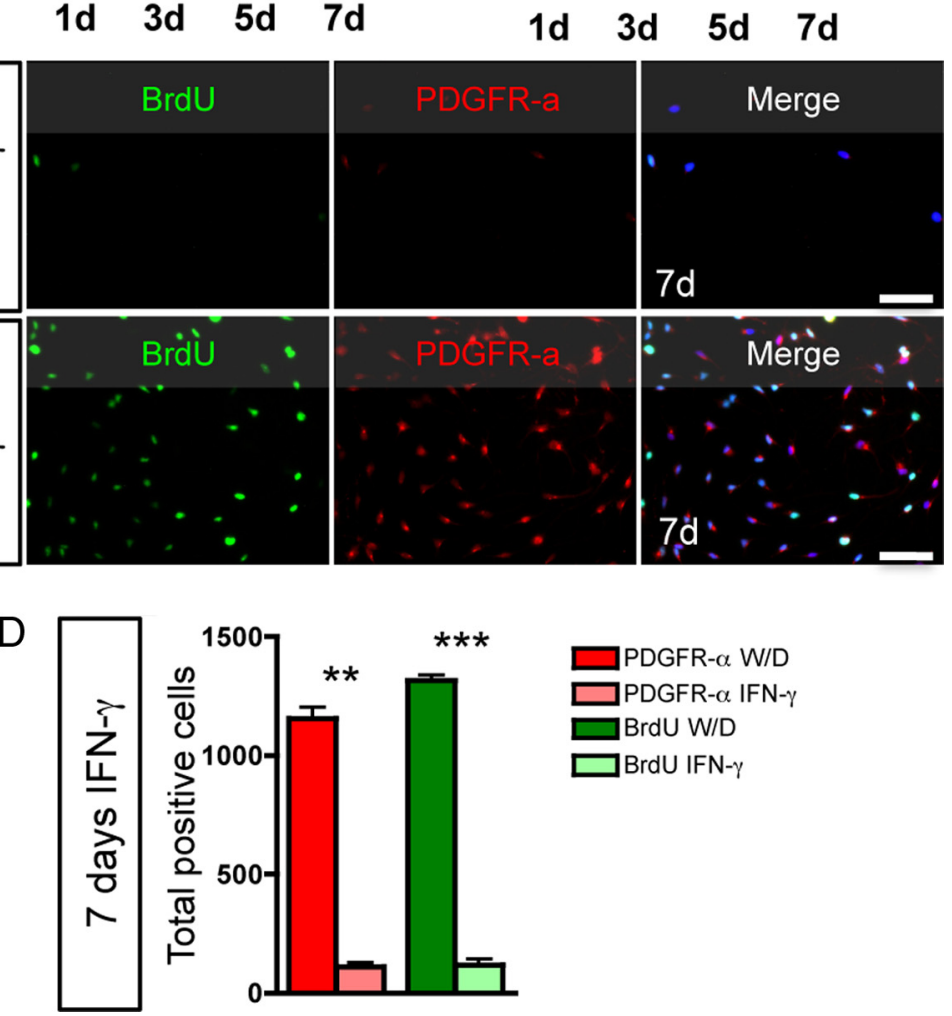

Figure 6. Long-term IFN- $\gamma$-induced quiescence is reversible. $0-2 \mathrm{~A} / 0 \mathrm{PCs}$ were grown at mass culture density and treated with IFN- $\gamma$ for $7 \mathrm{~d}$. In separate cultures, IFN- $\gamma$ was withdrawn and replaced with proliferation media (W/D) or growth in IFN- $\gamma$ was continued for the same number of days (IFN- $\gamma$ ). $\boldsymbol{A}, A t 3,5$, and $7 \mathrm{~d}$ W/D, there was significant upregulation of PDGFR- $\alpha$ expression $7 \mathrm{~d}\left({ }^{*} p<0.05,{ }^{* *} p<0.001\right.$, $t$ test). C, BrdU incorporation and PDGFR- $\alpha$ expression were measured in 0-2A/0PCs grown at mass culture density after W/D or continued IFN- $\gamma$. Scale bar, $50 \mu \mathrm{m}$. D, 0n W/D, both PDGFR- $\alpha$ expression and BrdU incorporation were significantly greater compared with continuous IFN- $\gamma\left({ }^{* *} p<0.005,{ }^{* * *} p<0.001\right.$, $t$ test). Note that, in the $7 \mathrm{dIFN}-\gamma$ group, these cells were exposed to IFN- $\gamma$ for a total of $14 \mathrm{~d}$ and remained alive and quiescent. Error bars represent mean \pm SEM.

finding makes it highly unlikely that the GFAP/A2B5-doublepositive cells we observed in previous experiments were attributable to type 1 astrocyte contamination in our cultures.

Although these data suggest that O-2A/OPCs are differentiating into astrocytes, it does not rule out the possibility that astrocyte progenitor cells or a subset $\mathrm{O}-2 \mathrm{~A} / \mathrm{OPCs}$ is responsible for the astrocyte generation. To test this possibility, we performed clonal analyses in the presence of BMP-4 alone or in combination with IFN- $\gamma$. As shown in Figure $8 D$, the average clone had fewer than five A2B5-positive cells at 3, 5, and $7 \mathrm{~d}$, indicating that these cells were not proliferating (Fig. $8 D, E$ ). There were similarly fewer than five GFAP-positive cells, on average, per clone at each time point examined, indicating that there is no subset of GFAPpositive cells that is proliferating (Fig. $8 F, G$ ). Collectively, these data indicate that virtually all cells from a single $\mathrm{O}-2 \mathrm{~A} / \mathrm{OPC}$ clone differentiated into GFAP/A2B5-double-positive astrocytes and 

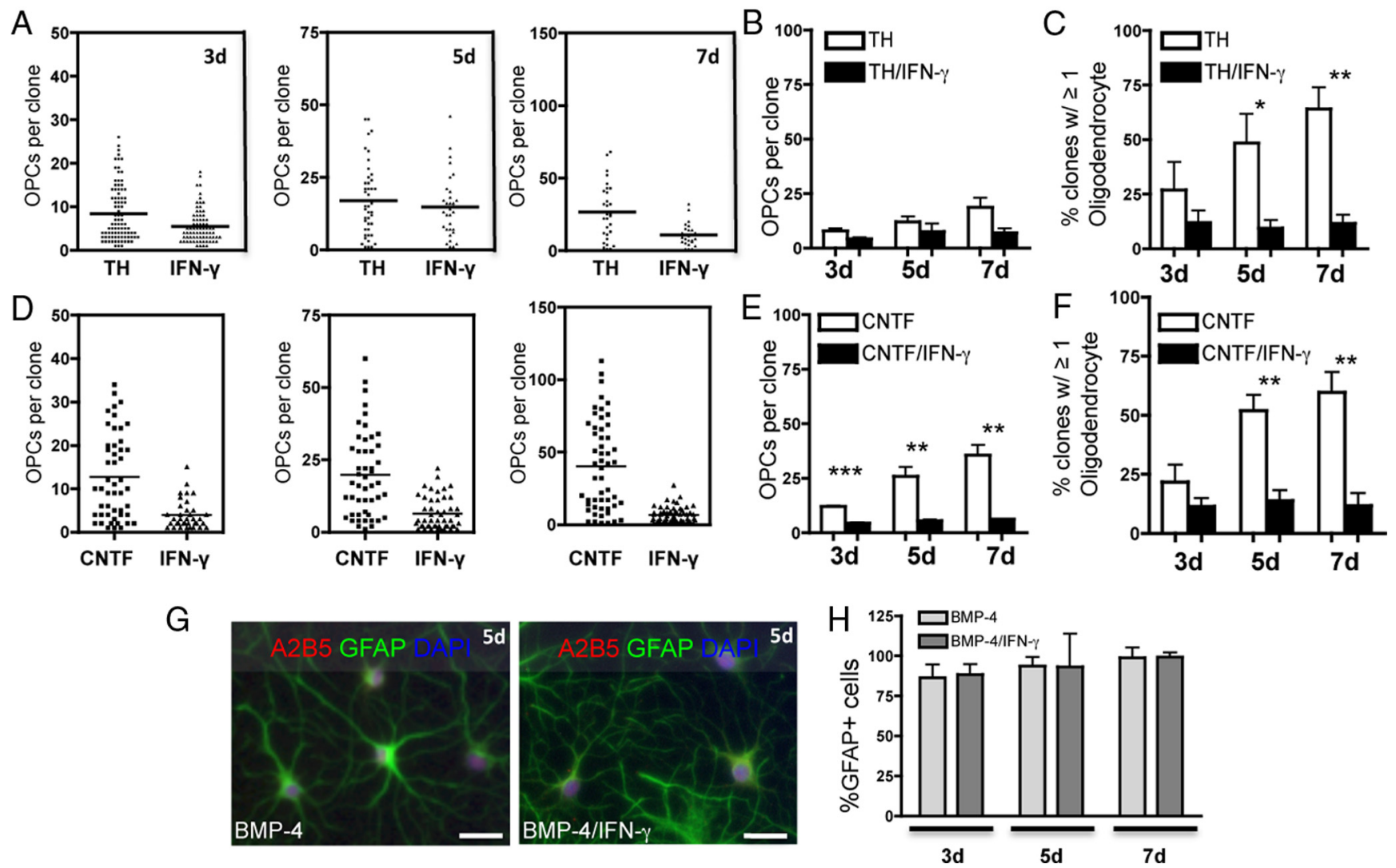

Figure 7. $0-2 \mathrm{~A} / \mathrm{OPC}$ differentiation into oligodendrocytes, but not astrocytes, is inhibited in the presence of IFN- $\gamma \cdot A, 0-2 \mathrm{~A} / \mathrm{OPCS}$ were grown at clonal density in oligodendrocyte differentiation conditions (1 $\mathrm{ng} / \mathrm{ml} \mathrm{PDGF-AA}$ and $40 \mathrm{~nm} \mathrm{TH})$ in the presence or absence IFN- $\gamma(10 \mathrm{ng} / \mathrm{ml})$. There were significantly fewer $0-2 \mathrm{~A} / \mathrm{OPCs}$ per clone found in differentiation conditions with the addition of IFN- $\gamma$ at $3 \mathrm{~d}$ compared with control (*** $p<0.001$, $t$ test), no difference at $5 \mathrm{~d}$, and a significant decrease in $0-2 \mathrm{~A} / 0 \mathrm{PC}$ after $7 \mathrm{~d}$ of differentiation treatment with IFN- $\gamma$ treatment compared with control $\left({ }^{* * *} p<0.001, t\right.$ test). Representative data from one experiment are shown. $\boldsymbol{B}$, Means of individual experiments were grouped, and data are presented as mean \pm SEM. IFN- $\gamma$ exposure had no effect on $0-2 \mathrm{~A} / 0 \mathrm{PC}$ proliferation in the presence of TH at any of the time points studied. C, Summary graph of multiple experiments in which GalC-positive oligodendrocytes were counted at each time point. At $3 \mathrm{~d}$, there was no difference in the number of clones with at least one GalC-positive oligodendrocytes in the presence or absence of IFN- $\gamma$. By $5 \mathrm{~d}$, there was a significant decrease in the number of clones containing oligodendrocytes $\left({ }^{*} p<0.05, t\right.$ test) and a greater decrease by $7 \mathrm{~d}\left({ }^{* *} p<0.01, t\right.$ test). $\boldsymbol{D}, 0-2 \mathrm{~A} / \mathrm{OPC}$ were induced to differentiate into oligodendrocytes with CNTF (10 ng/ml CNTF and $1 \mathrm{ng} / \mathrm{ml}$ PDGF-AA) and similar inhibition of differentiation was observed. The addition of IFN- $\gamma$ to CNTF-treated 0-2A/OPCs significantly decreased self-renewal at each time point $\left({ }^{* * *} p<0.001, t\right.$ test). Data are from one experiment. $\boldsymbol{E}$, Means of individual experiments were grouped, and data are presented as mean \pm SEM. There was a significant decrease in clones containing at least one GalC-positive oligodendrocyte in IFN- $\gamma$-treated cultures at 3,5 , and $7 \mathrm{~d}\left({ }^{* *} p<0.01\right.$, ${ }^{* * *} p<0.001, t$ test). $\boldsymbol{F}$, Summary graph of multiple experiments in which GalC-positive oligodendrocytes were counted at each time point. There were significantly fewer clones containing oligodendrocytes at 5 and $7 \mathrm{~d}$ with IFN- $\gamma$ treatment $\left({ }^{* *} p<0.01, t\right.$ test). G, $0-2 \mathrm{~A} / 0$ PCs were grown at mass culture density in the presence of the proastrocyte factor BMP- $4(10 \mathrm{ng} / \mathrm{ml}$; and $1 \mathrm{ng} / \mathrm{ml}$ PDGF-AA) with or without IFN- $\gamma(10 \mathrm{ng} / \mathrm{ml}$ ). Type 2 astrocytes (A2B5 and GFAP immunoreactive) were generated at equal frequency in both conditions. $\boldsymbol{H}$, Type 2 astrocytes were quantified from mass culture experiments as in $\boldsymbol{E}$ and are represented as the percentage GFAP-positive cells per total DAPI-positive nuclei. There is no difference in the proportion of type 2 astrocytes generated with or without IFN- $\gamma$. Scale bar, $25 \mu \mathrm{m}$.

that there is no other population of cells giving rise to the GFAPpositive astrocytes generated by IFN- $\gamma$ treatment.

\section{Discussion}

Our goal in these studies was to understand the sublethal response of O-2A/OPCs to IFN- $\gamma$, which has confounded investigators since it was tested as therapy in MS patients in which it exacerbated MS relapse (Panitch et al., 1987). IFN- $\gamma$ expression precedes the clinical symptoms of MS (Beck et al., 1988) and its expression correlates with EAE severity (Renno et al., 1994). Paradoxically, IFN- $\gamma$ has been shown to reduce the severity of EAE by intraventricular injection (Voorthuis et al., 1990), whereas depletion of IFN- $\gamma$ worsens EAE (Billiau et al., 1988; Duong et al., 1992), and IFN- $\gamma$ gene knock-out confers susceptibility to EAE in mice that are normally resistant (Krakowski and Owens, 1996). Recently, IFN- $\gamma$ signaling was found to decrease neuroinflammation and pathogenesis in the cerebellum and brainstem (Lees et al., 2008) and activate a cytoprotective stress response in EAE mice (Lin et al., 2007, 2008).
In vitro analyses of IFN- $\gamma$ (up to $200 \mathrm{ng} / \mathrm{ml}$ ) have been described by others to induce apoptosis in oligodendrocyte progenitors generated by the shake-off method (McCarthy and de Vellis, 1980), but these cultures were exposed to serum (Vartanian et al., 1995; Andrews et al., 1998; Baerwald and Popko, 1998; Chew et al., 2005; Horiuchi et al., 2006; Wang et al., 2010) and contain in a mixture of O-2A/OPCs, microglia, and astrocytes (Miller et al., 2007). In contrast, another group reported that IFN- $\gamma$ had no adverse effect on viability but inhibits proliferation (Agresti et al., 1996). Based on the contradictory results from various groups using mixed glial cell preparations, we set out to characterize the $\mathrm{O}-2 \mathrm{~A} / \mathrm{OPC}$ response to IFN- $\gamma$ in the absence of other cells. The perinatal progenitor cells used in our studies were highly purified from corpus callosum, whereas adult progenitors were isolated from the optic nerve, grown in culture for up to only one passage, and were never exposed to serum.

Our data demonstrate that IFN- $\gamma$ inhibits O-2A/OPC proliferation and induces differentiation of a subset of O-2A/OPCs into astrocytes. Our conclusion that IFN- $\gamma$ induces cell cycle exit 
as opposed to cell death or differentiation into oligodendrocytes is supported by several lines of evidence: First, IFN- $\gamma$ did not alter the number of clones, although there was a decrease in the amount of proliferation within each given clone at all time points examined (Fig. 2). Exposure also decreased BrdU incorporation (Fig. 3) and did not change the number of dead or dying cells as detected by either TUNEL (Fig. $1 A$ ) or activated caspase-3 staining (data not shown). Similarly, in differentiation conditions, with both $\mathrm{TH}$ and CNTF, there was no change in clone numbers with IFN- $\gamma$ but a decrease in the number of clones containing GalCpositive oligodendrocytes (Fig. 8). We also found that this response was robust in that adult O-2A/OPCs from the optic nerve also showed decreased self-renewal (Fig. 4). Second, IFN- $\gamma$ exposure had no effect on $\mathrm{O}-2 \mathrm{~A} / \mathrm{OPC}$ viability (Fig. 1). In long-term cultures, O-2A/OPCs treated with IFN- $\gamma$ for $>40 \mathrm{~d}$ showed no difference in viability compared with control cells (our unpublished observations). Third, the proliferation marker Ki-67 was downregulated on IFN- $\gamma$ treatment (Fig. 1 ), strongly indicating that a majority of cells were in phase $G_{0}$. Furthermore, the cell cycle inhibitor proteins $\mathrm{Rb}$ and $\mathrm{p} 27^{\mathrm{kip} 1}$ were both upregulated in response to IFN- $\gamma$ (Fig. 5). A recent report demonstrates that IFN- $\gamma$ upregulates IRF-1 in O-2A/OPCs (Wang et al., 2010), which has been shown to upregulate p $27^{\text {kip } 1}$ in cancer cells (Lee et al., 2005), and supports our conclusions with the important exception that, unlike Wang et al., we do not observe cell death. This discrepancy could be attributable to different cell isolation methods and/or the higher concentration of IFN- $\gamma$ they used. An alternative explanation of their viability data is that the decrease in MTT labeling in their cultures exposed to IFN- $\gamma$ is not an indication of cell death, as was concluded, but rather a lack of proliferation and/or metabolic activity. Fourth, DNA content, as analyzed by flow cytometry, robustly demonstrates that the vast majority of $\mathrm{O}-2 \mathrm{~A} / \mathrm{OPCs}$ were neither in $\mathrm{S}$ phase nor $\mathrm{G}_{2} / \mathrm{M}$ phase of the cell cycle (Fig. 3) but rather in $\mathrm{G}_{0} / \mathrm{G}_{1}$. This, coupled with the decrease in Ki-67 immunostaining, strongly suggests that the majority of these cells were in $G_{0}$. This observation is in contrast with a previous report (Chew et al., 2005), but these authors were studying the effect of higher concentrations of IFN- $\gamma$ on differentiating precursors, making it difficult to directly compare results. Fifth, the cell cycle exit induced by IFN- $\gamma$ was reversible (Figs. 6, 7).

Although IFN- $\gamma$ exposure decreased PDGFR- $\alpha$ expression, our data suggest that IFN- $\gamma$-mediated cell cycle exit is not primarily attributable to loss of PDGFR- $\alpha$. Inhibiting PDGFR- $\alpha$ degradation
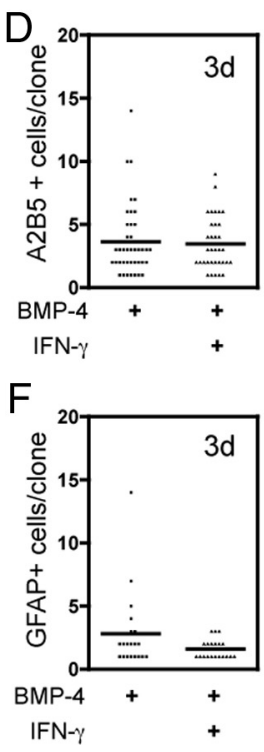
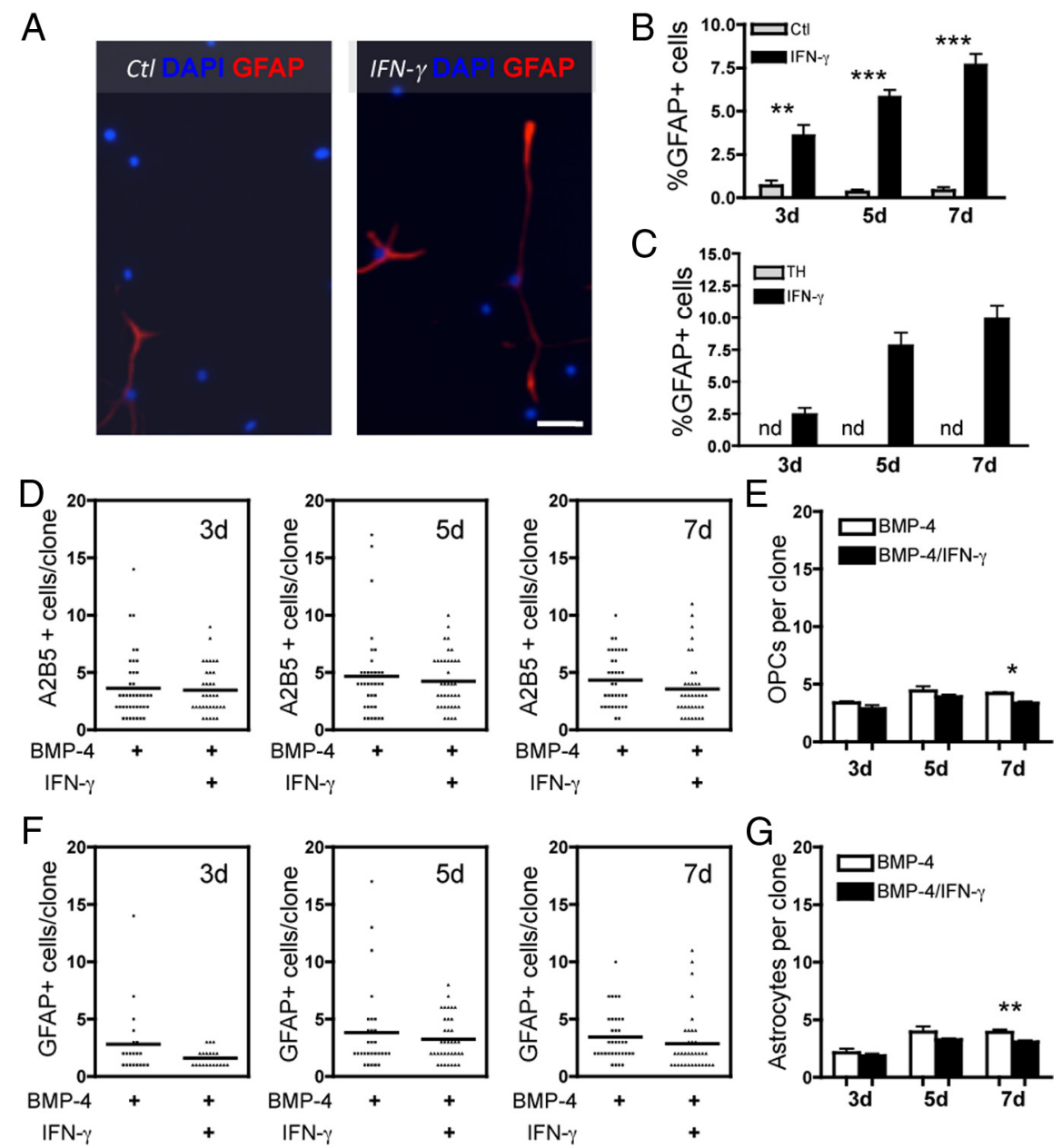

Figure 8. IFN- $\gamma$ promotes $0-2 \mathrm{~A} / \mathrm{OPC}$ differentiation into GFAP-positive astrocytes. $\boldsymbol{A}, 0-2 \mathrm{~A} / 0 \mathrm{PC}$ were grown at mass culture density in minimal media (DMEM/F12 with Sato components supplemented with $1 \mathrm{ng} / \mathrm{mI} P D G F)$ and treated with or without IFN- $\gamma$ $(10 \mathrm{ng} / \mathrm{ml})$. Cells were stained with anti-GFAP and DAPI at $5 \mathrm{~d}$. Scale bar, $50 \mu \mathrm{m}$. B, Quantification of 0-2A/OPC differentiation into GFAP-positive astrocytes at 3,5, and $7 \mathrm{~d}$. There was a significant increase in astrocyte differentiation in the presence of IFN- $\gamma$ versus control ( $3 d_{,}{ }^{* *} p<0.005 ; 5$ and $7 d_{,}{ }^{* * *} p<0.0001, t$ test). Note that the percentage of GFAP-positive cells in control was never more than $0.67 \%$. C, 0-2A/OPCs were grown at mass culture density in oligodendrocyte differentiation media (DMEM/F12 with Sato components supplemented with $1 \mathrm{ng} / \mathrm{mI} \mathrm{PDGF}$ and $40 \mathrm{~nm}$ TH $)$ and treated with or without IFN- $\gamma(10 \mathrm{ng} / \mathrm{ml})$. In the presence of thyroid hormone alone, no GFAP-positive cells were detected at any time point examined, but in the presence of IFN- $\gamma$, astrocyte generation is slightly higher than in $\boldsymbol{B}$. D, 0-2A/OPCs are responsible for generating IFN- $\gamma$-induced astrocytes. 0-2A/0PCs were grown at clonal density in astrocyte differentiation media with or without IFN- $\gamma(10 \mathrm{ng} / \mathrm{ml}) .0-2 \mathrm{~A} / 0 \mathrm{P}$ ( self-renewal, measured by the number of A2B5-positive/GalC-negative OPCs per clone, was not increased in by the addition of IFN- $\gamma$. Data are from one experiment. $\boldsymbol{E}$, Summary graph of means from individual experiments grouped and data presented as mean \pm SEM. IFN- $\gamma$ did not increase self-renewal at any time point and actually led to fewer $0-2 \mathrm{~A} / 0 \mathrm{PC}$ s per clone at $7 \mathrm{~d}\left({ }^{*} p<0.05, t\right.$ test). $\boldsymbol{F}$, Similar clonal cultures were stained with anti-GFAP, and the number of GFAP-positive cells per clone was quantified. There was no increase in proliferation of GFAP cells per clone with IFN- $\gamma$. Note the low numbers of cells per clone, indicating that there is no increase in astrocyte proliferation, although there is almost complete differentiation of all of the precursors into astrocytes. Data are from one experiment. G, Summary graph of means from individual experiments grouped and data presented as mean \pm SEM. IFN- $\gamma$ did not increase astrocyte proliferation at any time point and actually led to fewer astrocytes per clone at $7 \mathrm{~d}\left({ }^{* *} p<0.001, t\right.$ test).

did not abrogate the effect of IFN- $\gamma$ on O-2A/OPC self-renewal (Fig. $2 F, G)$. Moreover, O-2A/OPCs treated with both PDGF-AA and FGF-2 undergo similar cell cycle exit (Fig. $2 A-C$ ).

Exposure to IFN- $\gamma$ decreased differentiation of O-2A/OPCs into oligodendrocytes (Fig. 8). Interestingly, differentiation is not inhibited per se as cells exposed to IFN- $\gamma$ were still able to differentiate into astrocytes (Figs. 8). O-2A/OPC differentiation into type 2 astrocytes in culture has been shown in the presence of CNTF and extracellular matrix (Lillien et al., 1990; Mayer et al., 1994), and after exposure to BMPs (Mabie et al., 1997; Grinspan et al., 2000; Gomes et al., 2003; Samanta and Kessler, 2004; Hampton et al., 2007; Weible and Chan- 
Ling, 2007). This astrocyte differentiation is not restricted to in vitro conditions but also has been shown to occur in vivo. BMP-4 overexpression and conditional BMP receptor mutants both demonstrate that BMP signaling induces astrocyte generation at the expense of oligodendrocyte number in vivo (Gomes et al., 2003; Samanta et al., 2007). Rodent NG2 + progenitors can also give rise to astrocytes in the absence of ectopic or disrupted signaling (Aguirre and Gallo, 2004; Zhu et al., 2008; Guo et al., 2009) and human progenitors transplanted into mice differentiate into oligodendrocytes in the white matter and astrocytes when they migrate into gray matter (Windrem et al., 2004). O-2A/OPC differentiation into astrocytes is also observed in vivo in response to stab wounds or cryoinjury (Alonso, 2005; Buffo et al., 2005; Tatsumi et al., 2005; Hampton et al., 2007; Magnus et al., 2007). Our results also demonstrate that IFN- $\gamma$ can induce O-2A/OPC differentiation into astrocytes, even in the presence of pro-oligodendrocyte signaling factors such as $\mathrm{TH}$ and CNTF (Fig. 8) (data not shown). This observation is intriguing as mice overexpressing IFN- $\gamma$ under control of the MBP promoter have been shown to exhibit an increase in GFAP immunoreactivity as well as reactive gliosis in white matter tracts (Corbin et al., 1996). Our data suggest that IFN- $\gamma$ is associated with the generation of GFAP-positive astrocytes from O-2A/OPCs and not from type 1 astrocytes as IFN- $\gamma$ led to neither increased proliferation nor to upregulation of A2B5 or GFAP in cortical A2B5-negative type 1 astrocytes (data not shown). Type 2 astrocytes could formally also be progeny of a subpopulation of astrocyte progenitor cells (APCs), but it appears unlikely that our cultures contain APCs, however, as it has been shown that the survival of APCs is dependent on GGF (glial growth factor) (Mi and Barres, 1999), which is not present in our conditions. In addition, our clonal data show that virtually every cell in clones generated in the presence of BMP and IFN- $\gamma$ was immunoreactive for both A2B5 and GFAP and no clones contained cells that labeled with anti-GFAP only and could therefore be progeny of a putative APC. Together, our conclusions most strongly support the idea that the GFAP+/A2B5+ positive astrocytes in our cultures differentiated from O-2A/OPCs. These data suggest that endogenous O-2A/OPCs can directly contribute to IFN- $\gamma$ induced astrogliosis, a possibility that has not yet been examined.

These data demonstrate the potential for IFN- $\gamma$ to influence cell fate in CNS injury and inflammation in previously unrecognized ways. Although the environment in vivo is much more complex, high focal concentrations of IFN- $\gamma$ might initially lead to a decrease of $\mathrm{O}-2 \mathrm{~A} / \mathrm{OPC}$ numbers via apoptosis. After acute inflammation ends and the levels of IFN- $\gamma$ decrease (Franklin, 2002), O-2A/OPCs could then differentiate into astrocytes. Although this could reduce the number of progenitors available to generate oligodendrocytes, astrocyte generation might also be associated with local production of beneficial factors, as seen for type 1 astrocyte production of interleukin-11 (Zhang et al., 2006), nerve growth factor, brainderived neurotrophic factor, and neurotrophin-3 (Schwartz et al., 1993). Were this so, differentiation of O-2A/OPCs into astrocytes could represent a protective measure that helps to safeguard the remaining progenitor cells. Such an effect might help to explain the contradictory effects of IFN- $\gamma$ in vivo and would suggest that a positive outcome of inhibiting inflammation through therapeutic interventions is highly dependent on the time point of the intervention and local concentration of inflammatory cytokines like IFN- $\gamma$. Finally, more in vitro and in vivo investigation of IFN- $\gamma$ in combination with other inflammatory cytokines will advance our understanding of O-2A/OPC behavior and hopefully expose new therapeutic avenues.

\section{References}

Agresti C, D’Urso D, Levi G (1996) Reversible inhibitory effects of interferongamma and tumour necrosis factor-alpha on oligodendroglial lineage cell proliferation and differentiation in vitro. Eur J Neurosci 8:1106-1116.

Aguirre A, Gallo V (2004) Postnatal neurogenesis and gliogenesis in the olfactory bulb from NG2-expressing progenitors of the subventricular zone. J Neurosci 24:10530-10541.

Alonso G (2005) NG2 proteoglycan-expressing cells of the adult rat brain: possible involvement in the formation of glial scar astrocytes following stab wound. Glia 49:318-338.

Andrews T, Zhang P, Bhat NR (1998) TNFalpha potentiates IFNgamma-induced cell death in oligodendrocyte progenitors. J Neurosci Res 54:574-583.

Baerwald KD, Popko B (1998) Developing and mature oligodendrocytes respond differently to the immune cytokine interferon-gamma. J Neurosci Res 52:230-239.

Barres BA, Hart IK, Coles HS, Burne JF, Voyvodic JT, Richardson WD, Raff MC (1992) Cell death in the oligodendrocyte lineage. J Neurobiol 23:1221-1230.

Barres BA, Schmid R, Sendnter M, Raff MC (1993) Multiple extracellular signals are required for long-term oligodendrocyte survival. Development 118:283-295.

Beck J, Rondot P, Catinot L, Falcoff E, Kirchner H, Wietzerbin J (1988) Increased production of interferon gamma and tumor necrosis factor precedes clinical manifestation in multiple sclerosis: do cytokines trigger off exacerbations? Acta Neurol Scand 78:318-323.

Billiau A, Heremans H, Vandekerckhove F, Dijkmans R, Sobis H, Meulepas E, Carton H (1988) Enhancement of experimental allergic encephalomyelitis in mice by antibodies against IFN- $\gamma$. J Immunol 140:1506-1510.

Bögler O, Wren D, Barnett SC, Land H, Noble M (1990) Cooperation between two growth factors promotes extended self-renewal and inhibits differentiation of oligodendrocyte-type-2 astrocyte (O-2A) progenitor cells. Proc Natl Acad Sci U S A 87:6368-6372.

Bottenstein JE, Sato GH (1979) Growth of a rat neuroblastoma cell line in serum-free supplemented medium. Proc Natl Acad Sci U S A 76:514-517.

Buffo A, Vosko MR, Ertürk D, Hamann GF, Jucker M, Rowitch D, Götz M (2005) Expression pattern of the transcription factor Olig2 in response to brain injuries: implications for neuronal repair. Proc Natl Acad Sci U S A 102:18183-18188.

Burkhart DL, Sage J (2008) Cellular mechanisms of tumour suppression by the retinoblastoma gene. Nat Rev Cancer 8:671-682.

Casaccia-Bonnefil P, Hardy RJ, Teng KK, Levine JM, Koff A, Chao MV (1999) Loss of p27Kip1 function results in increased proliferative capacity of oligodendrocyte progenitors but unaltered timing of differentiation. Development 126:4027-4037.

Cayre M, Canoll P, Goldman JE (2009) Cell migration in the normal and pathological postnatal mammalian brain. Prog Neurobiol 88:41-63.

Chang A, Nishiyama A, Peterson J, Prineas J, Trapp BD (2000) NG2positive oligodendrocyte progenitor cells in adult human brain and multiple sclerosis lesions. J Neurosci 20:6404-6412.

Chew LJ, King WC, Kennedy A, Gallo V (2005) Interferon-gamma inhibits cell cycle exit in differentiating oligodendrocyte progenitor cells. Glia 52:127-143.

Corbin JG, Kelly D, Rath EM, Baerwald KD, Suzuki K, Popko B (1996) Targeted CNS expression of interferon- $\gamma$ in transgenic mice leads to hypomyelination, reactive gliosis, and abnormal cerebellar development. Mol Cell Neurosci 7:354-370.

Dawson MR, Levine JM, Reynolds R (2000) NG2-expressing cells in the central nervous system: are they oligodendroglial progenitors? J Neurosci Res 61:471-479.

Dawson MR, Polito A, Levine JM, Reynolds R (2003) NG2-expressing glial progenitor cells: an abundant and widespread population of cycling cells in the adult rat CNS. Mol Cell Neurosci 24:476-488.

Duong TT, St. Louis J, Gilbert JJ, Finkelman FD, Strejan GH (1992) Effect of anti-interferon-gamma and anti-interleukin-2 monoclonal antibody treatment on the development of actively and passively induced experimental allergic encephalomyelitis in the SJL/J mouse. J Neuroimmunol 36:105-115.

Franklin RJ (2002) Why does remyelination fail in multiple sclerosis? Nat Rev Neurosci 3:705-714.

Franklin RJ, ffrench-Constant C (2008) Remyelination in the CNS: from biology to therapy. Nat Rev Neurosci 9:839-855.

Gomes WA, Mehler MF, Kessler JA (2003) Transgenic overexpression of BMP4 increases astroglial and decreases oligodendroglial lineage commitment. Dev Biol 255:164-177. 
Grinspan JB, Edell E, Carpio DF, Beesley JS, Lavy L, Pleasure D, Golden JA (2000) Stage-specific effects of bone morphogenetic proteins on the oligodendrocyte lineage. J Neurobiol 43:1-17.

Guo F, Ma J, McCauley E, Bannerman P, Pleasure D (2009) Early postnatal proteolipid promoter-expressing progenitors produce multilineage cells in vivo. J Neurosci 29:7256-7270.

Hampton DW, Asher RA, Kondo T, Steeves JD, Ramer MS, Fawcett JW (2007) A potential role for bone morphogenetic protein signalling in glial cell fate determination following adult central nervous system injury in vivo. Eur J Neurosci 26:3024-3035.

Horiuchi M, Itoh A, Pleasure D, Itoh T (2006) MEK-ERK signaling is involved in interferon-gamma-induced death of oligodendroglial progenitor cells. J Biol Chem 281:20095-20106.

Ibarrola N, Mayer-Pröschel M, Rodriguez-Peña A, Noble M (1996) Evidence for the existence of at least two timing mechanisms that contribute to oligodendrocyte generation in vitro. Dev Biol 180:1-21.

Imitola J, Chitnis T, Khoury SJ (2005) Cytokines in multiple sclerosis: from bench to bedside. Pharmacol Ther 106:163-177.

Krakowski M, Owens T (1996) Interferon-gamma confers resistance to experimental allergic encephalomyelitis. Eur J Immunol 26:1641-1646.

Lee SH, Kim JW, Oh SH, Kim YJ, Rho SB, Park K, Park KL, Lee JH (2005) IFN- $\gamma$ /IRF-1-induced p27kip1 down-regulates telomerase activity and human telomerase reverse transcriptase expression in human cervical cancer. FEBS Lett 579:1027-1033.

Lees JR, Golumbek PT, Sim J, Dorsey D, Russell JH (2008) Regional CNS responses to IFN- $\gamma$ determine lesion localization patterns during EAE pathogenesis. J Exp Med 205:2633-2642.

Levine JM, Reynolds R, Fawcett JW (2001) The oligodendrocyte precursor cell in health and disease. Trends Neurosci 24:39-47.

Li Z, Dong T, Pröschel C, Noble M (2007) Chemically diverse toxicants converge on Fyn and c-Cbl to disrupt precursor cell function. PLoS Biol 5:e35.

Lillien LE, Sendtner M, Raff MC (1990) Extracellular matrix-associated molecules collaborate with ciliary neurotrophic factor to induce type-2 astrocyte development. J Cell Biol 111:635-644.

Lin W, Popko B (2009) Endoplasmic reticulum stress in disorders of myelinating cells. Nat Neurosci 12:379-385.

Lin W, Bailey SL, Ho H, Harding HP, Ron D, Miller SD, Popko B (2007) The integrated stress response prevents demyelination by protecting oligodendrocytes against immune-mediated damage. J Clin Invest 117:448-456.

Lin W, Kunkler PE, Harding HP, Ron D, Kraig RP, Popko B (2008) Enhanced integrated stress response promotes myelinating oligodendrocyte survival in response to interferon- $\gamma$. Am J Pathol 173:1508-1517.

Mabie PC, Mehler MF, Marmur R, Papavasiliou A, Song Q, Kessler JA (1997) Bone morphogenetic proteins induce astroglial differentiation of oligodendroglial-astroglial progenitor cells. J Neurosci 17:4112-4120.

Magnus T, Coksaygan T, Korn T, Xue H, Arumugam TV, Mughal MR, Eckley DM, Tang SC, Detolla L, Rao MS, Cassiani-Ingoni R, Mattson MP (2007) Evidence that nucleocytoplasmic Olig2 translocation mediates braininjury-induced differentiation of glial precursors to astrocytes. J Neurosci Res 85:2126-2137.

Mayer M, Bhakoo K, Noble M (1994) Ciliary neurotrophic factor and leukemia inhibitory factor promote the generation, maturation and survival of oligodendrocytes in vitro. Development 120:143-153.

McCarthy KD, de Vellis J (1980) Preparation of separate astroglial and oligodendroglial cell cultures from rat cerebral tissue. J Cell Biol 85:890 -902.

Menn B, Garcia-Verdugo JM, Yaschine C, Gonzalez-Perez O, Rowitch D, Alvarez-Buylla A (2006) Origin of oligodendrocytes in the subventricular zone of the adult brain. J Neurosci 26:7907-7918.

Mi H, Barres BA (1999) Purification and characterization of astrocyte precursor cells in the developing rat optic nerve. J Neurosci 19:1049-1061.

Miller BA, Crum JM, Tovar CA, Ferguson AR, Bresnahan JC, Beattie MS (2007) Developmental stage of oligodendrocytes determines their response to activated microglia in vitro. J Neuroinflammation 4:28.

Miller RH (2002) Regulation of oligodendrocyte development in the vertebrate CNS. Prog Neurobiol 67:451-467.

Noble M, Murray K, Stroobant P, Waterfield MD, Riddle P (1988) Plateletderived growth factor promotes division and motility and inhibits premature differentiation of the oligodendrocyte/type-2 astrocyte progenitor cell. Nature 333:560-562.

Noble M, Pröschel C, Mayer-Pröschel M (2004) Getting a GR(i)P on oligodendrocyte development. Dev Biol 265:33-52.

Panitch HS, Hirsch RL, Schindler J, Johnson KP (1987) Treatment of mul- tiple sclerosis with gamma interferon: exacerbations associated with activation of the immune system. Neurology 37:1097-1102.

Popko B, Corbin JG, Baerwald KD, Dupree J, Garcia AM (1997) The effects of interferon-gamma on the central nervous system. Mol Neurobiol 14:19-35.

Power J, Mayer-Pröschel M, Smith J, Noble M (2002) Oligodendrocyte precursor cells from different brain regions express divergent properties consistent with the differing time courses of myelination in these regions. Dev Biol 245:362-375.

Raff MC, Miller RH, Noble M (1983) A glial progenitor cell that develops in vitro into an astrocyte or an oligodendrocyte depending on culture medium. Nature 303:390-396.

Renno T, Lin JY, Piccirillo C, Antel J, Owens T (1994) Cytokine production by cells in cerebrospinal fluid during experimental allergic encephalomyelitis in SJL/J mice. J Neuroimmunol 49:1-7.

Richardson WD, Pringle N, Mosley MJ, Westermark B, Dubois-Dalcq M (1988) A role for platelet-derived growth factor in normal gliogenesis in the central nervous system. Cell 53:309-319.

Samanta J, Kessler JA (2004) Interactions between ID and OLIG proteins mediate the inhibitory effects of BMP4 on oligodendroglial differentiation. Development 131:4131-4142.

Samanta J, Burke GM, McGuire T, Pisarek AJ, Mukhopadhyay A, Mishina Y, Kessler JA (2007) BMPR1a signaling determines numbers of oligodendrocytes and calbindin-expressing interneurons in the cortex. J Neurosci 27:7397-7407.

Scholzen T, Gerdes J (2000) The Ki-67 protein: from the known and the unknown. J Cell Physiol 182:311-322.

Schwartz JP, Sheng JG, Mitsuo K, Shirabe S, Nishiyama N (1993) Trophic factor production by reactive astrocytes in injured brain. Ann N Y Acad Sci 679:226-234.

Tang XM, Beesley JS, Grinspan JB, Seth P, Kamholz J, Cambi F (1999) Cell cycle arrest induced by ectopic expression of p27 is not sufficient to promote oligodendrocyte differentiation. J Cell Biochem 76:270-279.

Tatsumi K, Haga S, Matsuyoshi H, Inoue M, Manabe T, Makinodan M, Wanaka A (2005) Characterization of cells with proliferative activity after a brain injury. Neurochem Int 46:381-389.

Tikoo R, Osterhout DJ, Casaccia-Bonnefil P, Seth P, Koff A, Chao MV (1998) Ectopic expression of p27Kip1 in oligodendrocyte progenitor cells results in cell-cycle growth arrest. J Neurobiol 36:431-440.

Vartanian T, Li Y, Zhao M, Stefansson K (1995) Interferon-gammainduced oligodendrocyte cell death: implications for the pathogenesis of multiple sclerosis. Mol Med 1:732-743.

Voorthuis JA, Uitdehaag BM, De Groot CJ, Goede PH, van der Meide PH, Dijkstra CD (1990) Suppression of experimental allergic encephalomyelitis by intraventricular administration of interferon-gamma in Lewis rats. Clin Exp Immunol 81:183-188.

Wang Y, Ren Z, Tao D, Tilwalli S, Goswami R, Balabanov R (2010) STAT1/ IRF-1 signaling pathway mediates the injurious effect of interferongamma on oligodendrocyte progenitor cells. Glia 58:195-208.

Weible MW 2nd, Chan-Ling T (2007) Phenotypic characterization of neural stem cells from human fetal spinal cord: synergistic effect of LIF and BMP4 to generate astrocytes. Glia 55:1156-1168.

Weinberg RA (1991) Tumor suppressor genes. Science 254:1138-1146.

Windrem MS, Nunes MC, Rashbaum WK, Schwartz TH, Goodman RA, McKhann G 2nd, Roy NS, Goldman SA (2004) Fetal and adult human oligodendrocyte progenitor cell isolates myelinate the congenitally dysmyelinated brain. Nat Med 10:93-97.

Wolswijk G (1998a) Chronic stage multiple sclerosis lesions contain a relatively quiescent population of oligodendrocyte precursor cells. J Neurosci 18:601-609.

Wolswijk G (1998b) Oligodendrocyte regeneration in the adult rodent CNS and the failure of this process in multiple sclerosis. Prog Brain Res 117:233-247.

Wolswijk G, Noble M (1989) Identification of an adult-specific glial progenitor cell. Development 105:387-400.

Zhang SC, Ge B, Duncan ID (1999) Adult brain retains the potential to generate oligodendroglial progenitors with extensive myelination capacity. Proc Natl Acad Sci U S A 96:4089-4094.

Zhang Y, Taveggia C, Melendez-Vasquez C, Einheber S, Raine CS, Salzer JL, Brosnan CF, John GR (2006) Interleukin-11 potentiates oligodendrocyte survival and maturation, and myelin formation. J Neurosci 26:12174-12185.

Zhu X, Bergles DE, Nishiyama A (2008) NG2 cells generate both oligodendrocytes and gray matter astrocytes. Development 135:145-157. 